Atıf Bilgisi: Nisan, F. ve Şentürk Kara, E. (2021). Muhammed Mursi’nin ölümünün Türk basınındaki yansimasi. INIF E-Dergi, 6(2), 244-268.

\title{
MUHAMMED MURSI'NIIN ÖLÜMÜNÜN TÜRK BASININDAKİ YANSIMASI
}

\author{
Doç. Dr. Fatma NISAN* \\ Doç. Dr. Eylem ŞENTÜRK KARA** \\ DOI: 10.47107/inifedergi.977162
}

Araștırma Makalesi***

Başvuru Tarihi: 01.08.2021

Kabul Tarihi: 13.09.2021

Öz

2010 yılında başlayan ve Ortadoğu coğrafyasına zarar veren Arap Baharı, söz konusu topraklarda hem hükümetleri hem de halkları etkilemiştir. Mısır'ın seçimle ilk defa başa geçen ve devrik beşinci cumhurbaşkanı olan Muhammed Mursi, davası uğruna Türkiye yönetimi ve kamuoyu tarafindan desteklenmiştir. Özellikle Mursi'nin duruşu ve dini kimliği Türkiye'de destek görmesi noktasında önemli bir nitelik taşımaktadır. Mısır'ın devrik lideri Muhammed Mursi, 17 Haziran 2019 tarihinde kuşkulu bir şekilde Kahire'de ölmüştür. 2013'ün Temmuz ayında askeri darbeyle devrildiğinden beri cezaevinde olan Mursi'nin, mahkeme salonunda söz istediği sırada hayatını kaybetmesi kuşkuyla karşılanmış ve onun bir suikasta kurban gittiği düşüncesi ortaya çıkmıştır. Mursi’nin ölümü Türkiye'de önemli bir yankı uyandırmış, hatta ülkenin dört bir yanında Muhammed Mursi için gıyabi cenaze namazı kılınmıştır. Bu düşünceden hareketle Türk yönetimi başta olmak üzere Türk halkı ve Türk ulusal basını tarafından da kayda değer derecede önemsenmiş ve gündemde tutulmuş olması, çalışmada Muhammed Mursi'nin ölümünün analizini gerekli kılmıştır. Bu çalışmanın amacı, Mısır'ın devrik lideri Muhammed Mursi'nin ölümünün Türk ulusal basınındaki yansımalarını ve sunuluş kapsamını irdelemektir. Çalışmada 25 ulusal gazetenin birinci sayfaları Mursi'nin ölümünün ardından 5 günlük süreçte eleştirel söylem analizi yöntemiyle incelenmiştir. Çalışmada Akşam, Anayurt, Aydınlık, Birgün, Cumhuriyet, Diriliş Postası, Evrensel, Güneş, Karar, Korkusuz, Milat, Milli Gazete, Ortadoğu, Sözcü, Star, Türkgün, Türkiye, Yeni Akit, Yeni Asya, Yeni Birlik, Yeni Çağ, Yeni Mesaj, Yeni Söz, Yeni Şafak ve Yurt gazetelerinin 18-22 Haziran 2019 tarihleri arasındaki sayıları incelenmiştir. Sonuç olarak Muhammed Mursi'nin ölümünün analiziyle ilgili olan çalışmada Mursi'nin ölümünün Türk ulusal basınının haber içeriklerine önemli ölçüde yansıdığı görülmüştür.

Anahtar Kelimeler: Muhammed Mursi, Mısır, Türk Basını, Eleştirel Söylem Analizi

\section{THE REFLECTION OF THE DEATH OF MUHAMMAD MORSI IN THE TURKISH PRESS}

\begin{abstract}
The Arab Spring, which started in 2010 and damaged the geography of the Middle East, impacted both governments and populations on the land concerned. Turkey and the Turkish public supported the activities of Mohammed Morsi, the first elected and ousted fifth president of Egypt. The mindset and religious identity of Morsi, in particular, have played an important role in getting Turkey's help. Mohammed Morsi, Egypt's overthrown leader, died suspiciously in Cairo on June 17, 2019. Morsi, who has been in jail since the failure of the July 2013 military coup, was suspected of 1 being assassinated after losing his life in the courtroom. The death of Morsi has had significant repercussions in Turkey, even in absentia funeral prayers for Mohammed Morsi around the country has been made. In this context, it has been necessary to analyze Muhammed Morsi's death that the Turkish administration, especially the Turkish people and the Turkish national press, highly regarded and kept it on the agenda. The purpose of this study is to analyze the reflections in the Turkish national press on the death of Mohammed Morsi, Egypt's ousted leader, and the way it has been presented on media. In the study, the first pages of 25 national newspapers were examined by critical discourse analysis method within 5 days following the death of Morsi. In the study, the issues of

\footnotetext{
* İnönü Üniversitesi, İletişim Fakültesi, Gazetecilik Bölümü, E-mail: fatma.nisan@ inonu.edu.tr, ORCID ID: 0000-00032741-9613

** İnönü Üniversitesi, İletişim Fakültesi, Gazetecilik Bölümü, E-mail: eylem.kara @inonu.edu.tr, ORCID ID: 0000-0002$1349-6442$

*** Yazar / yazarlar, makalede araştırma ve yayın etiğine uyulduğuna ve kullanılan fikir ve sanat eserleri için telif hakları düzenlemelerine riayet edildiğine yönelik beyanda bulunmuştur.
} 
Akşam, Anayurt, Aydınlık, Birgün, Cumhuriyet, Diriliş Postası, Evrensel, Güneş, Karar, Korkusuz, Milat, Milli Gazete, Ortadoğu, Sözcü, Star, Türkgün, Türkiye, Yeni Akit, Yeni Asya, Yeni Birlik, Yeni Çağ, Yeni Mesaj, Yeni Söz, Yeni Şafak and Yurt newspapers between 18-22 June 2019 were examined. As a result, in the study on the analysis of Mohammed Morsi's death, it was seen that Morsi's death was significantly reflected in the news content of the Turkish national press.

Keywords: Muhammed Morsi, Egypt, Turkish Press, Critical Discourse Analysis

\section{Giriş}

Yakın yıllarda herkesin duyduğu Arap Baharı, 2010'da Tunus'ta başlamış ve kısa sürede Arap coğrafyasındaki birçok ülkeye sıçramıştır. Sıçradığı ülkelerde sadece toplumları değil, aynı zamanda ülkelerin yönetimlerini de ciddi oranda etkileyen Arap Baharı ile birlikte ülkelerin yöneticileri koltuklarını devretmek durumunda kalmıştır. Arap coğrafyasındaki bu olaylar hem dünyanın hem de medyanın gündemine oturmuştur. Arap Baharı'nın Mısır topraklarına sıçramasıyla birlikte Hüsnü Mübarek iktidarı son bulmuş ve Mısır'da demokratik yolla ilk kez gerçekleşen seçimler sonrasında Muhammed Mursi, cumhurbaşkanı olmuştur. İktidarı çok fazla sürmeyen Mursi, Türkiye tarafından önemli derecede desteklenmiştir. Mursi'nin Türkiye tarafından desteklenmesinin ardında, Türkiye ile ortak bir düşünceye ve inanca sahip olması yatmaktadır. Yıllarca tutuklu bulunduğu cezaevinde kötü şartlar altında bırakıldığı iddia edilen Mursi, 17 Haziran 2019 tarihinde şüpheli bir şekilde Kahire'de duruşma salonunda ölmüştür. Kimi çevreler ve ülkeler tarafindan kuşkuyla karşılanan bu olayın gerçekleşmiş olması en başından beri Mursi'yi destekleyen Türkiye'de, hem halk hem de iktidar tarafından üzüntüyle karşılanmıştır. Türkiye'nin her tarafında Mursi için gıyabi cenaze namazlarının kılınmasının yanı sıra başta Cumhurbaşkanı Recep Tayyip Erdoğan olmak üzere devletin önemli mercileri tarafından Mursi'nin ölümü üzerine tepkiler gerçekleştirilmiştir. İktidarın ve halkın önemsediği Mursi'nin ölüm haberi ulusal basının da ilgi gösterdiği ve haberlerinde önemli derecede işlediği bir konu olmuştur.

$\mathrm{Bu}$ çerçeveden hareketle çalışmanın amacını, Mısır'ın devrik lideri Muhammed Mursi'nin ölümünün Türk ulusal basınındaki yansımalarını ve sunuluş kapsamını irdelemek oluşturmuştur. Çalışmada; Akşam, Anayurt, Aydınlık, Birgün, Cumhuriyet, Diriliş Postas1, Evrensel, Güneş, Karar, Korkusuz, Milat, Milli Gazete, Ortadoğu, Sözcü, Star, Türkgün, Türkiye, Yeni Akit, Yeni Asya, Yeni Birlik, Yeni Çağ, Yeni Mesaj, Yeni Söz, Yeni Şafak ve Yurt gazetelerinin 18-22 Haziran 2019 tarihleri arasındaki sayıları incelenmiştir. Milliyet, Hürriyet ve Sabah gibi gazetelerin sayılarına ulaşılamadığından bu gazeteler analiz edilememiştir. 25 ulusal gazetenin birinci sayfalarına Mursi'nin ölümünün ardından 5 günlük süreci analiz edildiği çalışmada eleştirel söylem analizi yöntemi kullanılmıştır.

\section{Misır'da Arap Baharı}

Arap Baharı; Arap coğrafyasında bulunan Tunus'ta ortaya çıkıp birçok Arap ülkesini etkileyen, yönetimleri değiştirmeye yönelik meydana gelen silahl1, siyasi, protestolu, toplumsal ve bölgesel bir halk hareketidir (Ayhan, 2011, s. 18). En yaygın kullanım Arap Baharı ifadesi olsa da, bu harekete "Arap İsyanı, Arap Uyanışı, Arap Devrimi, Arap Baharı ve Arap Kışı” gibi isimler de verilmiştir (Dede, 2011, s. 23-24). Bu hareket, 17 Aralık 2010 tarihinde Tunuslu Muhammed Buazizi'nin kendini yakması ile başlamıştır. Bu durumun temel nedeni olarak konunun uzmanları, uzun süredir bölgede toplumların huzursuzluğu, biriken gerilim ve rejimlerin gittikçe artan meşruiyet sorunlarını göstermiştir (Kışlakç1, 2012, s. 123; Usul, 2011, s. 1).

Aslında Arap Baharı'nı yüksek fiyatlar, konut sorunu gibi dinamikler ortaya çıkarmıştır (Bacık, 2011, s. 17). Bunun yanı sıra Arap ülkelerinin dışa kapalı ekonomileri, 
tarıma dayalı bir altyapıya sahip olmaları, ekonomik durumun çok iyi olmaması, yoksulluk, gelir dağılımındaki adaletsizlik, işsizlik ve bireyciliğin ağır basması (Öztoprak, 2012, s. 9), siyasi yozlaşmalar, gıda yetersizliği, ifade özgürlügüne getirilen kısıtlamalar enflasyon gibi olumsuzluklara karşı bir tepki olarak ortaya çıkmıştır. Arap Baharı, kısa zamanda Arap coğrafyasında önemli etkiler doğurmuştur (Dede, 2011, s. 23-24). Bu durum, Arap Baharı'nın sosyolojik, ekonomik, psikolojik gibi her yönüyle irdelenmesi gereken bir hareket olduğunu ortaya koymuştur.

Arap Baharı, Ortadoğu'da demokrasi ve özgürlük alanında atılacak adımlar noktasında halkın beklentilerini arttırmıştır (Aşkar Karakır ve Aknur, 2015, s. 132). Bu beklentiler kimi zaman istenilen yönde kimi zamansa istenilmeyen yönde cevap bulmuştur. "Arap Baharı eylemleri sonucunda bölgedeki iktidarların bazılarında aktörler değişmiş, bazılarında, halk lehine olan iktidarlarda kısmi değişiklikler yapılmış, bazılarında ise değişim olmamıştır" (Taş, 2012, s. 14). Dolayısıyla Arap Baharı, Ortadoğu'da baskı ve otoriteye dayalı olan yönetimlere karşı ortaya çıkan halk hareketlerini yansıtmak ve süreci bir demokratikleşme dalgası biçiminde anlatmak amacıyla kullanılmıştır (Dede, 2011, s. 23-24).

Tunus'ta ortaya çıkıp Kuzey Afrika ve Ortadoğu ülkelerine yansıyan Arap Baharı, Suriye'de iç savaşa, Libya'da iç savaşın yanı sıra dış müdahaleye, Tunus, Misır ve Libya'da hükümetlerin devrilmesine, Ürdün, Cezayir, Suudi Arabistan ve Fas gibi ülkelerde geniş boyutta olmasa da çeşitli reformların gerçekleşmesine sebep olmuştur (Göçer ve Çınar, 2015, s. 51). Arap Baharı'yla birlikte bu ülkelerde demokrasi adına adımlar atılmış, seçimler gerçekleştirilmiş, halk yeni yöneticilerini seçmiştir. Ancak bölge ülkelerinin yönetimlerinde bulunan engellerden kaynaklı olarak bu süreç tamamlanmadan bölgede eskiye dönüş yaşanmıştır (Koraltan, 2016, s. 34).

Arap Baharı'nın gerçekleştiği önemli ülkelerden biri Mısır olmuştur. "Mısır, batı ve doğunun buluşma noktası olan coğrafi konumu ile Arap coğrafyasına da lider ülke olabilme niteliğine sahip kilit bir ülke konumundadır" (Duran ve Y1lmaz, 2012, s. 58). Arap Baharı olaylarıyla ön plana çıkan Mısır, yüzyıllarca farklı ülkeler tarafından yönetilmiştir. Mısır, yabancı güçlerin hükümranlığından 1952 'de Britanya Krallığı tarafından desteklenen monarşi rejimini ortadan kaldırarak kurtulmuştur. Bu süreçten sonra cumhuriyet olarak yönetilen Misır'da kralların yerine otoriter diktatörler geçmiştir. Sonrasında ise, otoriter rejim 2011'de patlak veren Arap Baharı ayaklanmalarıyla yok olmuştur (Telli, 2012, s. 66). Mısır'daki Arap Baharı, Arap coğrafyasında yaşayan halkların uzun yıllardır yönetildikleri baskıcı rejimlere ciddi bir başkaldırı niteliğinde olmuştur. 25 Ocak 2011'de başlayan ve kısa bir süre içerisinde milyonlarca Mısırlının katıldığı gösteriler, 18 gün gibi kısa bir sürede sonuç vermiştir. $\mathrm{Bu}$ gösterilerle $30 \mathrm{y} 1 \mathrm{l}$ boyunca iktidarı elinde tutan Hüsnü Mübarek devrilmiş (Telci, 2014, s. 83) ve Arap Baharı sonrasında Mısır'da askeri darbe meydana gelmiştir (Doster, 2014, s. 183).

Günümüzdeki Mısır'ın durumu değerlendirildiğinde; Mısır'da ortaya çıkan mülteci krizinin etkisiyle Arap Baharı'nın küresel bir sorun haline dönüştüğü görülmektedir. Arap Baharı hareketi, demokrasinin getirilmesi yönünde başlatılmış olsa da Arap toplumlarının demokrasiye yönelik tecrübesiz ve yetersiz olmaları radikal olanla bir araya gelince oluşan yeni düzen, tam anlamıyla düzensizlik olmuştur (Güzelipek, 2016, s. 10).

\section{Darbeden Sonra Türkiye Mısır İlişkileri}

Mısır ve Türkiye'nin dini ve tarihsel açıdan köklü bağları bulunmaktadır. Bu tarihsel bağlar, gerçekte günümüzde de Türkiye ve Misır arasındaki ilişkilerin dostane ve samimi bir şekilde devam etmesine öncülük edecek güçtedir (siyasetdergisi.com.tr, 2020). Arap Baharı'ndan sonra seçimle başa geçen Muhammed Mursi, Müslüman Kardeşler 
kökenlidir. 30 Haziran 2012'de Mursi'nin Cumhurbaşkanlığı seçimlerini kazanması ile birlikte, Mısır'da siyasi iktidar sivil bir yönetime geçmiştir (Sarıaslan, 2019, s. 538). Bu yeni süreç, Türkiye-Mısır ilişkileri için önemli bir dönüm noktası olmuştur. İki ülke tarafından yapılan karşılıklı ziyaret ve ticaret hacmindeki artış, bu durumun önemli göstergeleridir. Ayrıca bu dönem iki ülke ilişkilerinin "Altın Çağı" olarak da nitelendirilmiştir (Akgün ve Senyücel Gündoğar, 2014, s. 4). Muhammed Mursi'nin yönetimine Türkiye'den yapılan ilk ziyaret dönemin Cumhurbaşkanı Abdullah Gül tarafından, ikinci ziyaret ise dönemin Dışişleri Bakanı Davutoğlu tarafından gerçekleştirilmiştir. Mısır'ın o dönemdeki Cumhurbaşkanı Mursi ise 30 Eylül 2012'de Türkiye'yi ziyaret etmiş ve AK Parti Kongresi'nde önemli açıklamalarda bulunmuştur (Kaya, 2018, s. 474-475). Mursi'nin bu ziyareti sirasında ayrıca 2 milyar dolarlık kredi sözleşmesi ve ek ticaret anlaşmaları imzalanmıştır (Akgün ve Senyücel Gündoğar, 2014, s. 2). Daha sonrasında ise, dönemin Başbakanı Recep Tayyip Erdoğan, kalabalık bir heyetle Mısır'a bir ziyaret gerçekleştirmiştir (Kaya, 2018, s. 475).

Arap Baharı'ndan sonra Misır'ın bir y1llık demokrasi denemesi, 3 Temmuz 2013 tarihinde kesintiye uğramıștır. Mursi tarafından Genel Kurmay Başkanlığına getirilen Abdülfettah Es- Sisi liderliğindeki ordu darbesiyle Mursi devrilmiştir (Telci, 2017, s. 476). Demokratik sisteme geçiş sürecinde seçilmiş bir yönetimin iktidara geldiği Misır, o coğrafyada süreçle birlikte askeri darbeyi yaşayan tek ülke olmuştur. Misır'da meydana gelen askeri darbe, Hüsnü Mübarek döneminden geriye kalan kadronun yerini koruduğunu göstermiştir (Uysal, 2014, s. 58).

Mısır'da 2013 yılında yaşanan Abdulfettah Es- Sisi darbesinden sonra MisırTürkiye ilişkilerinde ağır bir kriz meydana gelmiş ve diplomatik ilişkilerde kopma yaşanmıştır (siyasetdergisi.com.tr, 2020). Darbe sonrasında yaşanan gelişmeler, Türkiye ve Mısır ilişkilerini siyasi kriz sürecine sürüklemiştir (Akgün ve Senyücel Gündoğar, 2014, s. 4). Kriz etkisini siyasal alanda gösterirken Mısır'ın yeni yönetimi, “Anadolu Ajansı ve TRT Türk ofislerinin kapatılması ya da personel sayısının düşürülmesi konularında baskı yaparken, Türk İşbirliği ve Koordinasyon Ajansı Başkanlığının (TIKKA) Mısır'daki yardım faaliyetlerinin sonlandırıldığını" açıklamıştır (Telci, 2017, s. 309). Bu süreçte iki ülke büyükelçilerini karşılıklı olarak çekmiş ve ilişkiler 23 Kasım 2013 tarihinden bu yana maslahatgüzar seviyesine indirilmiştir (siyasetdergisi.com.tr, 2020).

Türkiye ile Mısır'ın Dışişleri Bakanları arasında kısa görüşmeler gerçekleşmiştir. Mısır'ın İstanbul Başkonsolosluğu ile Ankara Büyükelçiliği ve Türkiye'nin İskenderiye Başkonsolosluğu ile Kahire Büyükelçiliğgi faaliyetlerini sürdürmektedir. Ayrıca, Türkiye ile Mısır arasında ortak tarihi mirastan güç alan köklü ekonomik ve toplumsal bağlar muhafaza edilmektedir. Mısır'da halen yaklaşık 3 bin 500 vatandaşımız ikamet etmektedir. Türk ve Misırlı müteşebbisler arasında sık sık görüşmeler ve karşılıklı ziyaretler gerçekleştirilmektedir. Ayrıca, iki ülke arasında akdedilen bir anlaşma temelinde 2010 yılında Kahire'de açılan Yunus Emre Kültür Merkezi faaliyetlerine devam etmektedir (mfa.gov.tr, 2020).

\section{Mursi’nin Ölümünün Türk Basınındaki Yansımasının Analizi}

1951'de Nil Deltası'nın Şarkiya bölgesindeki El-Advah köyünde doğan Muhammed Mursi, 1970'lerde Kahire Üniversitesinde mühendislik okudu. Doktorasını Amerika Birleşik Devletleri'nde yapıp ülkesi Mısır'a döndüğünde, Zagazig Üniversitesinin mühendislik bölümünün başına geçti. Bilim kariyerinin yanında Müslüman Kardeşler Hareketi'nde de yükselen bir isim oldu. 2000-2005 yılları arasında bağımsız milletvekili olarak Misır Meclisi'nde yer ald1. Hitabet kabiliyeti ile dikkat çeken Mursi, 2012'de Müslüman Kardeşler'in cumhurbaşkanı adayı oldu. Seçim kampanyasında Mursi, devrik 
Cumhurbaşkanı Hüsnü Mübarek'in tekrar gelme ihtimaline yönelik olarak kendisini “siper" olarak tanıttı. 2012'de seçimleri kazandığında, "tüm Mısırlıların cumhurbaşkanı" olacağı konusunda söz verdi. Mursi, İslamcı kesimin siyasi olarak gücü tekeline almasına sebep verdiği, iktidarı Müslüman Kardeşler Hareketi çevresinde topladığı ve iktidara gelmesine olanak sağlayan isyanın sebeplerinden olan Mısır ekonomisini yönetişi gibi konularda eleştirildi (bbc.com, 2020).

Kasım 2012'de Mursi'ye karşı Mısır'da muhalefet artmaya başladı. Mursi'nin üzerinde çalıştığı ve muhaliflerin "şeriat getirmekle" eleştirdiği anayasa çalışması sırasında Mursi, cumhurbaşkanına daha çok yetki veren bir kararnameyi imzaladı. Protestolardan sonra söz konusu kararnamenin kapsamını daralttı. Buna rağmen çoğunluğunu İslamcı kesimin oluşturduğu Anayasa Komisyonu'nun, bir taslağı aynı dönemde onaylamasının ardından ülke yeniden karıştı. Bu durum karşısında Mursi, taslak anayasanın referanduma sunulacağı 15 Aralık 2012 tarihine kadar silahlı kuvvetlere devlet kurumlarını koruma yetkisi veren bir kararname imzaladı. Muhalif kanat bu durumu olağanüstü hal ilanı olarak yorumlarken ordu, bir süre sonra kışlaya geri döndü. Daha sonra Mursi taraftarları ve muhalifleri arasında çıkan çatışmalarda 50'nin üzerinde kişi öldü. 29 Ocak 2013 tarihinde dönemin Genelkurmay Başkanı Abdülfettah Es- Sisi bir uyarıda bulundu. Bu uyarı, siyasi krizin devletin çöküşüne sebep olabileceği şeklindeydi. Mursi'nin güvenliği sağlayamadığı ve ekonomiyi düzeltemediği gerekçesiyle Nisan 2013'te muhaliflerden oluşan Temerrüt Hareketi imza kampanyası başlattı. Bu hareket Mısır'ı yeniden bir seçime götürmeyi amaçliyordu (bbc.com, 2020).

Mursi'nin Misır Cumhurbaşkanı olarak yemin ettiği günün yıldönümünde, 30 Haziran 2013'te, Temerrüt milyonlarca kişinin katıldığı bir protesto gösterisi düzenledi. Ordu, toplumsal talepleri tatmin edecek bir "yol haritası" ortaya koymadığı müddetçe Mursi'ye ültimatom vererek müdahale edebileceği uyarısında bulundu. 3 Temmuz 2013 tarihinde ordu yönetime müdahale ederek anayasayı askıya aldığını açıkladı ve ülkeyi seçimlere götürecek bir teknokrat geçiş hükümetinin kurulacağını ilan etti. Açıklamayı "darbe" olarak tanımlayıp kınayan Mursi, ordu tarafindan gizli bir yere götürüldü ve ondan haftalarca haber alınamadı. Mursi'nin yokluğunda taraftarları Kahire'de sokağa çıktı ve onun serbest bırakılarak göreve iade edilmesini talep etti. Eylemler haftalarca sürdükten sonra ordu, 14 Ağustos'ta Kahire'deki iki ayrı protestocu kampına müdahale ederek kilit konumdaki Müslüman Kardeşler üyelerini tutukladı. Protestolara yönelik yapılan silahlı müdahalelerde, bin kadar Mısırlı hayatını kaybederken geçiş hükümeti yaşananları "terörle mücadele" şeklinde tanımladı (bbc.com, 2020).

2015'te Mursi, “Aralık 2012'de göstericilerin gözaltına alınması ve onlara işkence yapılması talimatı vermek" suçlamasıyla 20 yıl hapis cezası, 2011'de İslamcı militanların cezaevinden kaçmaları olayında rol oynadığı iddiasıyla yargılandığı davada ise idam cezasına çarptırıldı. Yüksek Mahkeme, 2016 yılında Mursi ile ilgili idam kararını bozdu. Ancak Mursi aynı yıl Katar için casusluk yaptığı gerekçesiyle yargılanarak suçlu bulundu ve müebbet aldı. Mısır'ın eski Cumhurbaşkanı Muhammed Mursi, 67 yaşında mahkeme salonunda hayatını kaybettiğinde ise Hamas'la temaslarına yönelik bir diğer casusluk davası için hâkim karşısındaydı (bbc.com, 2020).

\subsection{Yöntem}

$\mathrm{Bu}$ çalışmada eleştirel söylem analizi yöntemi kullanılmıştır. Egemenlik tarafından yapılandırılan her söylem, tarihsel olarak üretilmekte ve yorumlanmaktadır. Bu egemenlik yapıları, güçlü grupların ideolojilerinde meşrulaştırılmaktadır (Wodak, 2002, s. 12). Dili sosyal pratik olarak gören (Wodak ve Meyer, 2009, s. 5) eleştirel söylem analizinin amacı, sosyal eşitsizliği eleştirel olarak incelemektir (Weiss ve Wodak, 2003, s. 15). Bunun yanı 
sıra ayrıca eleştirel söylem analizi, söylemsel adaletsizlik ve onun sonuçlarının kurbanları olan gruplarla desteklemektedir. Meşru olmayan egemenliğe karşı direnen eleştirel söylem analizi, pratikte engelleme için rehber olduğu gibi söylemsel pratikler, kötüye kullanımın eleştirel bir değerlendirmesine izin vermektedir (van Dijk, 2009, s. 64). Baskıyı çözümlemenin yanı sıra eşitsiz güç ilişkilerine direnme olanaklarını da ortaya koymaya çalışan eleştirel söylem analizinde, egemen yapılar, yani anlamın üretimindeki ideoloji ve gücün etkileri gizlenmektedir. Böylece doğal formlar haline dönüşür. Direnme ise, yaratıcılık eylemleri içinde sabit söylemsel pratiklerin kırılması olarak görülmektedir (Özer, 2018, s. 21). İşte bu nedenler, çalışmada eleştirel söylem analizinin kullanımını gerekli kılmıştır.

Mursi'nin ölümünün Türk ulusal basınına yansımasının analiz edildiği bu çalışmada incelenen gazetelerin yayın çizgilerine dikkat edilmiştir. Buna göre sol çizgiyi temsilen; Cumhuriyet, Sözcü, Evrensel, Birgün, Aydınlık, Korkusuz ve Yurt, muhafazakâr veya sağ çizgiyi temsilen; Yeni Akit, Yeni Asya, Yeni Şafak, Milli Gazete, Diriliş Postası, Yeni Söz, Milat, Türkiye, Yeni Birlik, Akşam, Güneş, Yeni Mesaj, Star ve Karar, milliyetçi sağ1 temsilen ise; Yeni Çağ, Türkgün, Ortadoğu ve Anayurt gazetelerinin konuya yaklaşımları analiz edilmiştir. Çalışmada bu gazetelerin 18-22 Haziran 2019 tarihleri arasındaki sayıları incelenmiş̧tir. Milliyet, Hürriyet ve Sabah gibi gazetelerin sayılarına ulaşılamadığı için bu gazeteler inceleme dışında bırakılmıştır.

\subsection{Bulgular}

Akşam gazetesi, 18 Haziran 2019 tarihli sayısında Muhammed Mursi'nin ölümünü "Mursi, duruşmada hayatını kaybetti" başlığıyla küçük bir haber şeklinde duyurmuştur. Haber metninde Mursi'nin Mısır'ın demokratik yolla seçilen ilk devlet başkanı olduğuna vurgu yapan gazete, Mursi'nin 2013'te Misır Devlet Başkanı Abdülfettah Es- Sisi'nin darbesiyle iktidardan uzaklaştırıldığının ve darbeciler tarafından tutuklandığının altını çizmiştir. Kırmızı zemin üzerinde "Erdoğan: Mursi şehit" ifadesine yer verilen haberde, Mursi'nin parmaklıklar arkasındaki görüntüsünün yer aldığı fotoğrafi kullanılmıştır. Böylelikle Mursi'nin kötü şartlar altında ölmüş olması nedeniyle "ş̧ehit" olarak değerlendirilebileceğinin vurgusu yapılmıştır.

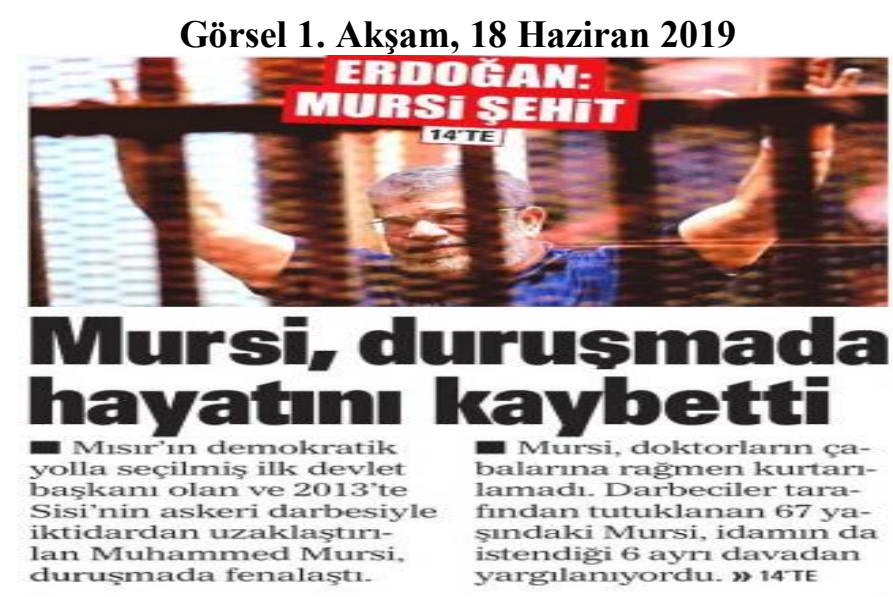

19 Haziran 2019 tarihli sayısında Akşam gazetesi, Mursi için Türkiye'nin dört bir yanında gıyabi cenaze namazının kılındığıyla ilgili bilgi vermiştir. Cumhurbaşkanı Erdoğan'ın da namaza katıldığını, kanıt olarak gösteren gazete, Erdoğan'ın 'Bunun normal bir ölüm olduğuna inancım yok." ifadelerini doğrudan kullanarak Mursi'nin ölümünü şüpheli bulduğunu ima etmiştir. Aynı sayıdaki bir başka haberde ise "Cenazesi bile darbecileri korkuttu” başlığı kullanılırken haber metninde, Mursi’nin köyünde defnedilme 
vasiyetine rağmen, Kahire yakınlarında apar topar toprağa verildiğine dikkat çekmiştir. Akşam, beş günlük süre zarfında olayı sadece iki gün birinci sayfasına taşımıştır.

Anayurt gazetesi, 19 Haziran 2019 tarihli sayısında Erdoğan'ın konuyla ilgili açıklamasına "Mursi'nin hayatını kaybetmesini seyreden insanlığı kınıyorum" başlığıyla yer vermiştir. Gazete, haberin metninde ise Erdoğan'ın "Mursi'nin darbeyle indirilmesini, hücrede eziyet çektirilmesini ve hayatını kaybetmesini seyreden Batı dünyasını ve insanlığı kınıyorum." şeklindeki ifadelerini kullanarak, Mursi'nin çektiği eziyetlere Erdoğan'ın söylemleriyle dikkat çekmek istemiştir. Gazete beş gün boyunca konuyla ilgili sadece bu habere yer vermiştir.

Görsel 2. Anayurt, 19 Haziran 2019

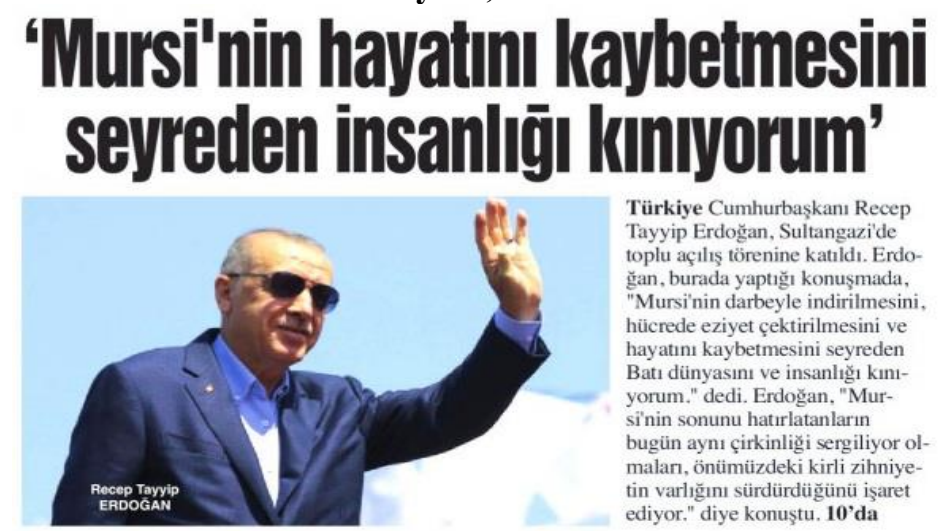

Birgün gazetesi, Mursi'nin ölüm haberini 18 Haziran 2019 tarihli sayısında "Mursi hayatını kaybetti" başlığıyla duyurmuştur. Birçok gazetenin Mursi'nin parmaklıklar arkasındaki fotoğrafını kullanmasının aksine Birgün, Mursi'nin kravatlı ve takım elbiseli fotoğrafına yer vermiştir. Gazete, haber metninde Mursi için "Müslüman Kardeşler Örgütü üyesi ve eski Mısır Cumhurbaşkanı" nitelemelerini kullanmıştır. Gazete, diğer birçok gazetenin aksine Mursi'nin demokratik yolla seçilen ilk cumhurbaşkanı olduğunu vurgulamamakla birlikte Cumhurbaşkanı Erdoğan'ın Mursi'nin ardından "Şehidimiz" dediğinin altını çizerek dolaylı yoldan Erdoğan'ın söylemini eleştirmiştir. 21 Haziran 2019 tarihli sayısında da eleştirisini sürdüren Birgün, Hayri Kozanoğlu'na ait köşe yazısında “Erdoğan'ın Mursi sevdası" başlığıyla birlikte "Kafesteki bir tutsağın mahkeme salonunda yaşamını yitirmesi bir insanlık trajedisidir. Adı Mursi de olsa. Ancak hiçbir şey Mursi'yi bir demokrasi şehidi yapmaz." ifadelerine yer vermiş̧ir. Bu ifadeler, iktidar yanlısı gazetelerin aksine, Birgün gazetesinin Mursi'yi, "şehit" kabul etmediğini gösterirken Mursi için "şehit" söylemlerini de eleştirmiştir.

Görsel 3. Birgün, 18 Haziran 2019

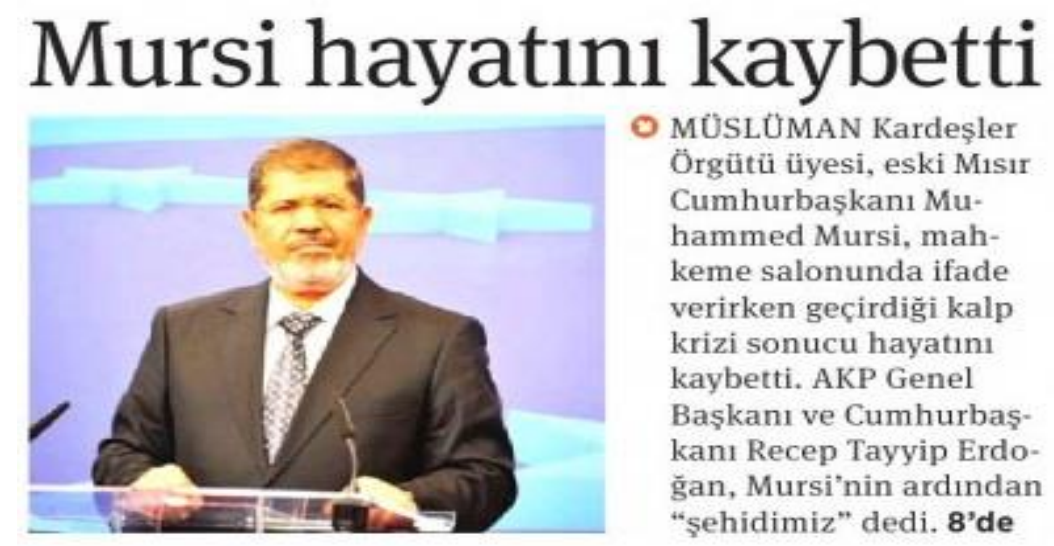


Mursi'nin ölüm haberini birinci sayfasında duyurmayan Cumhuriyet gazetesi, 19 Haziran 2019 tarihli sayısında "Mursi'ye gıyabi cenaze namazı" başlıklı habere yer vermiş ve bu namazın Diyanet İşleri Başkanlığının talimatıyla kılındığını belirterek Mursi'nin ölümü karşısında devletin tavrını, dolaylı yoldan ortaya koymuştur. Haber metninde gazete, Mursi için “Mısır'ın devrik cumhurbaşkanı” nitelemesini kullanırken Mursi'nin ölüm nedeninin kalp krizi olduğunun iddia edildiğini yazmıştır. Gazete konuyla ilgili başka bir habere birinci sayfasında hiç yer vermemiştir.

Görsel 4. Cumhuriyet, 19 Haziran 2019

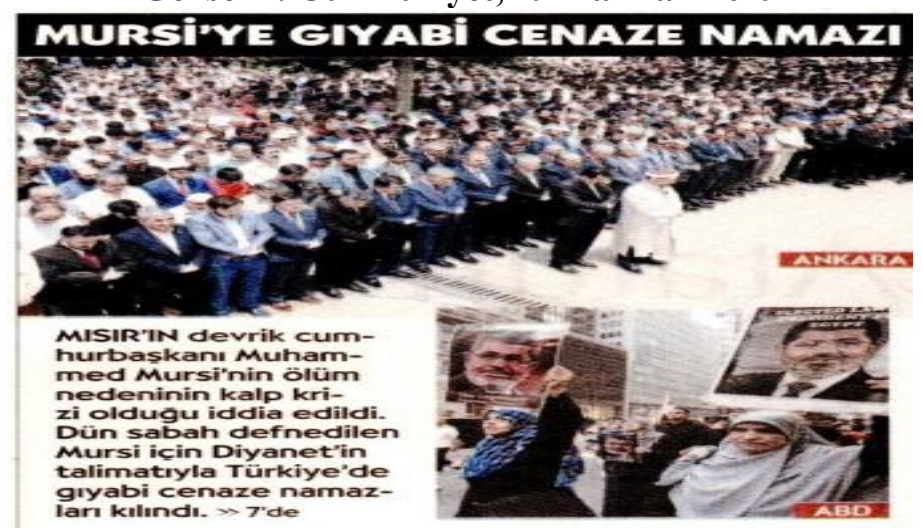

Diriliş Postası gazetesi, 19 Haziran 2019 tarihli sayısında sürmanşette "Şehit Muhammed Mursi'nin ardından" ve "Yılmad1, yenilmedi iman kalesini yüceltti" ifadelerine yer vererek, haberin ayrıntılarının iç sayfada yer alacağının bilgisini vermiştir. $\mathrm{Bu}$ haberde dikkat çeken nokta, Mursi'nin "şehit” olarak nitelendirilmiş olmasıdır. Gazete aynı sayfada konuyla ilgili iki ayrı haberi daha kullanmıştır. İlk haberde "Mursi için gıyabi cenaze namazı kılındı" başlığı kullanılırken haber metninde Mursi'nin demokratik seçimlerle cumhurbaşkanlığını kazandığı vurgusu yapılmıştır. Haber metninde Mursi için "şehit", Sisi için ise "zalim" nitelemesi kullanılmıştır. Konuyla ilgili diğer haber ise "Yunan'dan çirkin temenni!" başlığıyla verilmiştir. Haberin spotunda "Cunta rejiminin adım adım ölüme götürdüğü Mursi'nin vefatı Yunan medyasında 'Erdoğan'ın yakın dostu öldü' çizgisinde verildi. Haberlere yapılan yorumlarda 'Onun sonu da aynı olsun' şeklideki çirkin temennilerin sıklı̆̆ı göze çarptı” ifadeleri kullanılırken Yunan medyası haberde eleştirilmiş ve hastalıklı ilan edilmiştir. Haber fotoğrafı olarak da Mursi ve Erdoğan'ın yan yana olan görselleri kullanılmıştır. Haber metninde Mursi için "Mısır'ın meşru yollarla seçilmiş ilk ve tek cumhurbaşkanı" nitelemesi kullanılmıştır. Gazete, 20 Haziran 2019 tarihli sayısında "20 dakika Mursi'nin ölmesini beklediler" başlıklı haberde "Ülkesinin özgürlük savaşında asla boyun eğmeyen Misır'ın demokratik yöntemlerle seçilmiş ilk ve tek Cumhurbaşkanı Muhammed Mursi, 20 dakika boyunca ölüme terk edildi. Tek suçu yüreğinde taşıdı̆̆ı imanla Batılı sömürgecilerin uykularını kaçırmak olan Mursi, 6 yıl boyunca türlü baskı ve işkencelere maruz kalmıştı. " ifadelerine yer verilmiştir. 21 Haziran 2019 tarihli sayısında gazete, Erdoğan'ın "Mursi'nin ölümüne göz yummayacağı." ifadelerine yer vermiştir. Gazete, 22 Haziran 2019 tarihli sayısında "Mursi'nin mezarını sadece İsrail'e açtılar" başlı̆̆ıyla verdiği haberde, "Cunta yönetimi 6 yıllık tecrit ve işkenceyle ölüme mahkûm ettiği Mısır'ın demokratik yollarla seçilmiş ilk Cumhurbaşkanı Muhammed Mursi'nin defnedildiği mezarlığı sadece Siyonistlere açtı.” şeklindeki ifadeleri dikkat çekmiştir. Bu söylemleriyle gazete, konuyla ilgili durduğu yeri açık açık göstermiştir. 


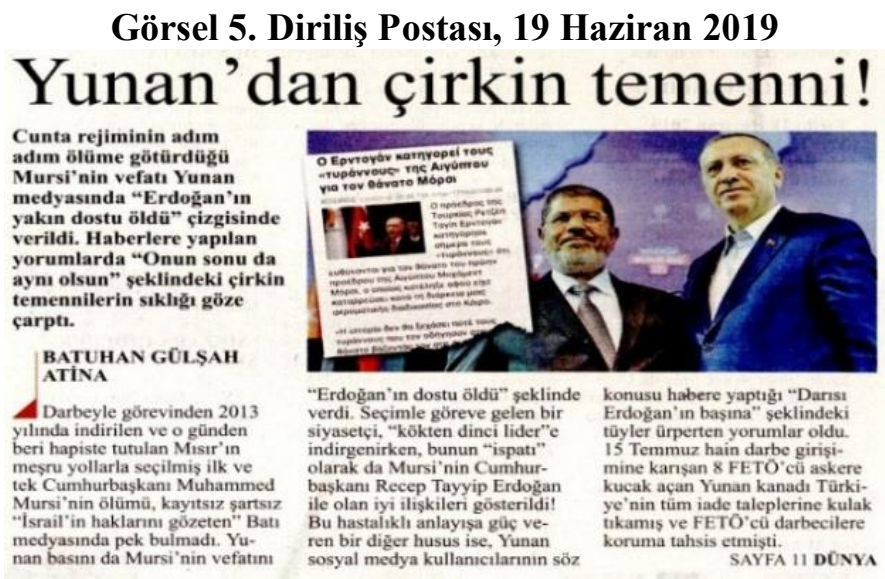

Evrensel gazetesi, 19 Haziran 2019 tarihli sayısında "Mursi öldü, en çok AKP üzüldü” başlığını atmıştır. Gazete haber metninde "Mısır'ın devrik Cumhurbaşkanı ve Müslüman Kardeşler temsilcisi Muhammed Mursi yargılandığı duruşmada öldü” ifadelerine yer vermiştir. Mursi'nin ölüm haberine Türkiye'nin en çok tepki gösteren ülkelerden biri olduğunun belirtildiği haberde, Cumhurbaşkanı Erdoğan'ın "şehidimiz" ifadesini, AK Parti Sözcüsü Ömer Çelik'in ise "Cansız bedeni bile cesaret abidesidir" ifadesini kullandığı bildirilmiştir. Haberin sonunda iktidar yanlısı medyanın da Erdoğan ve Çelik'in ifadelerine benzer şekilde ifadeler kullandığı iddia edilerek eleştirilmiştir. Haber fotoğrafı olarak ise Erdoğan ve Mursi'nin yan yana olduğu fotoğraf tercih edilmiştir. İncelemenin yapıldığı dönemde Evrensel gazetesi analiz edilen konuyla ilgili başka bir habere yer vermemiştir.

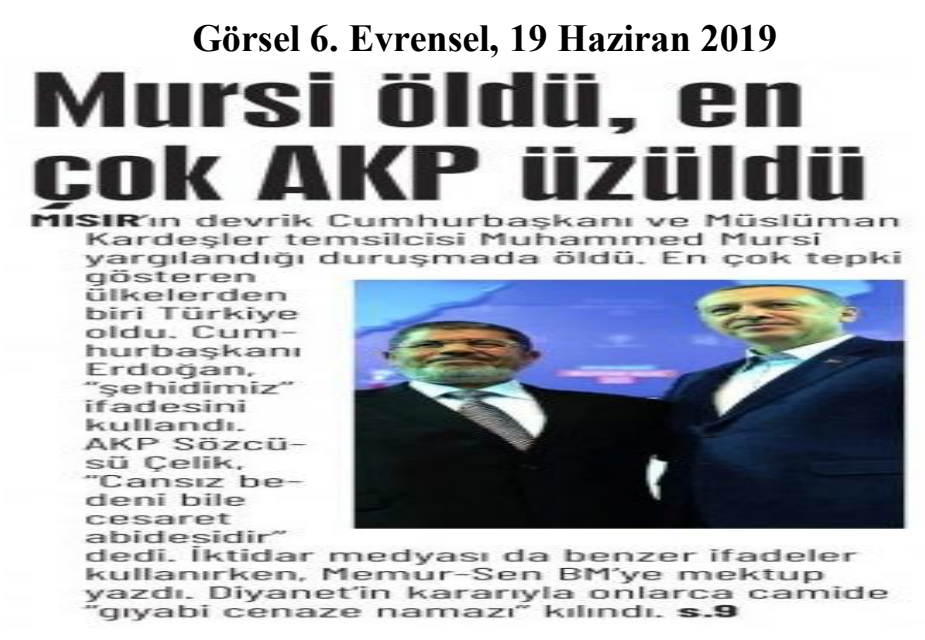

Güneş gazetesi, 18 Haziran 2019 tarihli sayısında Cumhurbaşkanı Erdoğan'ın "Muhammed Mursi mahkemede şehit oldu" ve "O zalimler asla unutulmayacak" şeklindeki ifadelerini başlığına taşımıştır. Gazete haber metninde Erdoğan'ın “Mursi, inandı̆̆ dava uğruna verdiği mücadele sırasında hayatını kaybeden bir şehittir. Tarih şehadetine yol açan zalimleri asla unutmayacak." şeklindeki ifadelerine yer vermiştir. Haberde, Mursi'nin parmaklıklar ardında elini veda eder tarzda kaldırdığı bir fotoğrafı kullanılmıştır. Gazete 19 Haziran 2019 tarihli sayısında "Mursi'ye gıyabi cenaze namazı" başlığını ve konuyla ilgili bir fotoğrafı vermiştir. 20 Haziran 2019 tarihli sayısında gazete, "Ölüme terk etmişler" başlığını ve başlığın altında demir parmaklıklar ardındaki Mursi'nin fotoğrafını kullanmıştır. Fotoğrafın altında ise, "20 dakika müdahale yok" başlığını kullanan gazete, haber metninde Mursi'nin Misır'ın demokratik yollarla seçilmiş ilk ve tek cumhurbaşkanı olduğunu yazmıştır. Gazete haberde Mursi'nin ölümünü şüpheli bulmuş ve 
güvenlik görevlilerinin baygınlık geçiren Mursi'ye 20 dakikadan fazla süre müdahale etmeyerek onu ölüme terk ettiğinin altını çizerek eleştirel bir söylem üretmiştir.

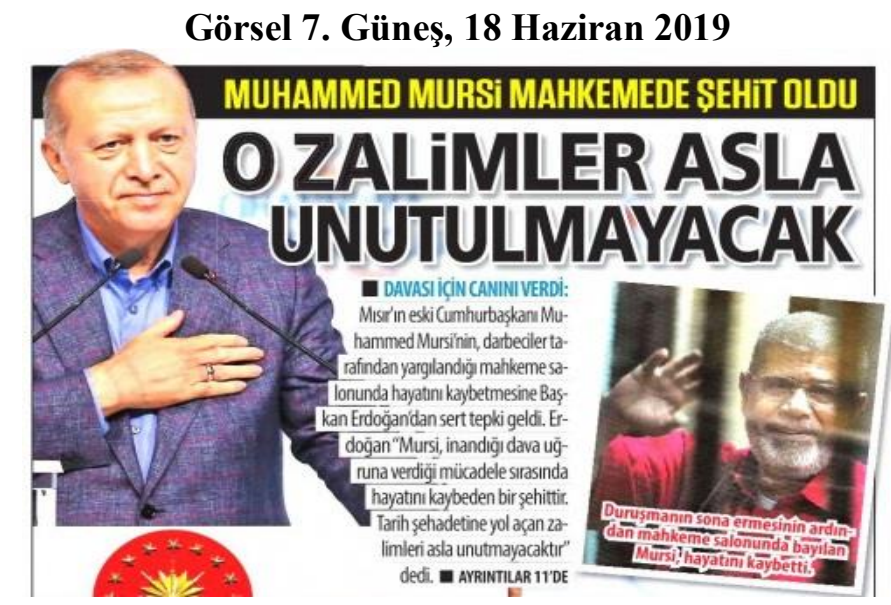

Birçok gazetenin “Öldü” diye duyurduğu Mursi’nin hayatını kaybettiği olayı, Karar gazetesi, 18 Haziran 2019 tarihli sayısında "Mursi şehit" başlığıyla sürmanşetten duyurmuştur. Mısır Cumhurbaşkanı Sisi'nin yanı sıra Mursi'nin parmaklıklar ardındaki fotoğrafına yer veren gazete, “Darbeci Sisi'nin devirdiği Mısır'ın seçilmiş ilk Cumhurbaşkanı Mursi, mahkeme salonunda hayatını kaybetti." ifadelerini spotta kullanmıştır. Sarı renkle "Son söze izin verilmedi” ifadelerine vurgu yapılarak Mursi'nin mağduriyeti gösterilmiştir. Haberde ise Misır medyası kaynak gösterilerek Mursi'nin hâkimden söz istediği ancak hâkimin ona söz hakkı vermeyerek duruşmayı bitirmesi üzerine Mursi'nin fenalaştığını yazmıştır. Gazete, haberin sonunda ise "Dünyanın gözleri önünde ölüme sürüklenen Mursi için İslam dünyasından 'şehit oldu' mesajları yağdı." ifadelerine yer vererek Mursi'nin şehit olduğu söylemini dini bir boyut kazandırarak üretmiştir. 19 Haziran 2019 tarihli sayısında Karar, "Türkiye Mursi için tek safta" diyerek gıyabi cenaze namazının fotoğrafını yansıtmış ve tüm Türkiye'nin yas tuttuğu imasını çizmiştir. Gazete, Sisi için "darbeci" nitelemesini haberlerinde kullanmıştır. 20 Haziran 2019 tarihli sayısında gazete sayfa eteğinde "Kafeste 20 dakika ölümünü izlediler" başlığını kullanırken haber metninde ise " 6 yıldır kendisini deviren darbeci Sisi'nin zindanlarında tutulan..." ifadelerinin yanı sıra cinayet şüphesine dikkat çekmiştir.

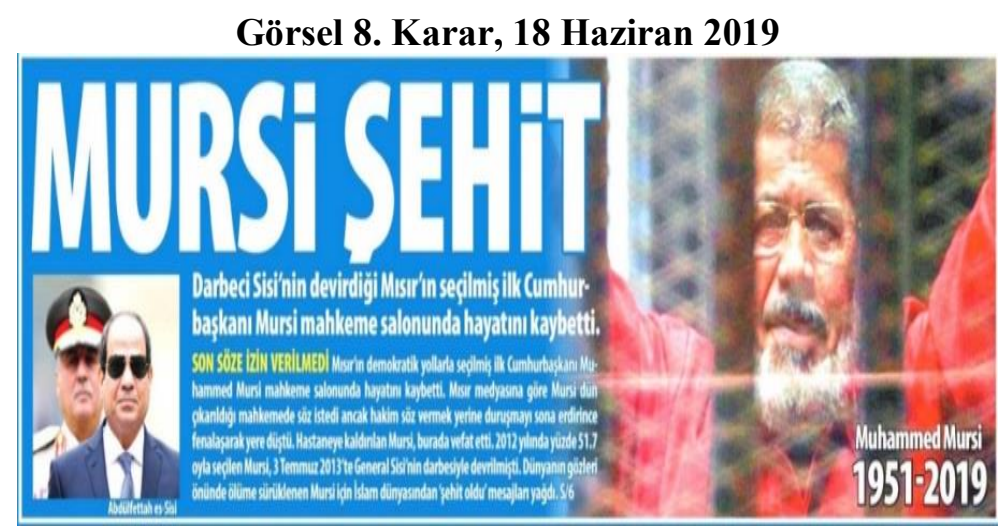

18 Haziran 2019 tarihli sayısında Milat gazetesi, başlığında "Zulüm altında şehit düştü” diyerek bazı gazetelerin aksine Mursi’yi şehit gördüğünü göstermiştir. Gazete haberde, Mursi'nin darbeyle görevinden uzaklaştırıldığını ve Mısır'ın demokratik yollarla seçilmiş ilk cumhurbaşkanı olduğunu vurgulamıştır. Haberin sonunda gazete, Mursi'ye uygulanan zulmü göstermek için Mursi'nin tek kişilik hücrelerde tam bir izolasyona tabi tutulduğunun altını çizmiş ve haberde Mursi'nin parmaklıklar ardındaki fotoğrafına yer 
vermiştir. 19 Haziran 2019 tarihli sayısında Milat, konuya önemli derecede yer ayırmış ve "Şehitler ölmez" başlıklı manşetinin üst başlığında "Mursi, batının köpeği Sisi yönetimince katledildi" ifadesini kullanmıştır. Gazete, böylelikle Sisi üzerinden batının eleştirisini de yapmış ve Sisi'nin batı ülkeleri için çalıştığını ima etmiştir. Milat, ifadelerini desteklemek için Bakara Suresi'ndeki 'Şehitler için 'ölüler' demeyin. Hayır, onlar diridirler, fakat siz bilemezsiniz" şeklindeki 154'üncü ayeti sarı zeminde vermiştir. Haberin "Ölürüm ama dönmem" başlığıyla verdiği bölümde "Mısır' da seçilmiş ilk Cumhurbaşkanı Muhammed Mursi, muhakemesi boyunca konuşturulmadı, hakarete ve işkencelere maruz kaldı. Ancak hiçbir zaman cesur tavrından geri durmayarak 'Sonu ölüm olsa da mücadelemden vazgeçmem.' dedi." ifadelerine yer verilerek Mursi'nin yaşadığı zorluklarla birlikte kararlı ve cesur bir duruşunun olduğu sergilenmeye çalışılmıştır. Gazete haberin devamında "Esaretten şehadete" ve "Sisi alarm ilan etti" ara başlıklarına yer vererek gelişmeleri Mursi'nin yanında durarak aktarmıştır. Gazete Mursi'nin fotoğrafının yan tarafında "Mısır'da seçimlerde göreve gelen ilk Cumhurbaşkanı şehit Muhammed Mursi" ifadelerine yer vermiştir. Gazete, Türkiye'deki Mursi için gıyabi cenaze namazlarını "Türkiye Mursi için kıyama durdu" başlığıyla yansıtmıştır. Gazete konuyla ilgili olarak "BM (Birleşmiş Milletler), cinayeti araştırmalı", "Ölmedi öldürüldü”, "Kasten öldürüldü” ve "Naaşından korktular" başlıklı haberlere de yer vererek, Mursi'nin şüpheli ölümü üzerine yapılan açıklamalara dikkat çekmiştir.

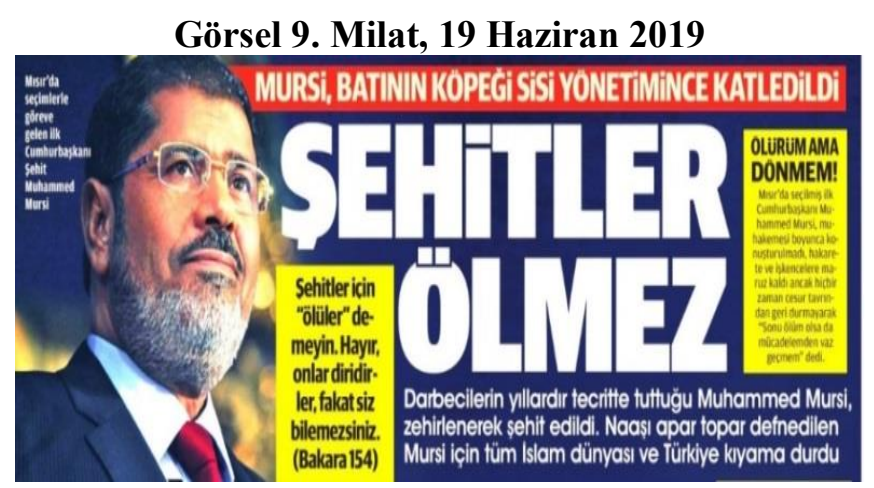

“Ölüme terk ettiler" başlıklı haberi 20 Haziran 2019 tarihli sayısında kullanan Milat, Mursi'nin parmaklıklar ardındaki fotoğrafını yine kullanmıştır. Başka gazeteler Mursi'ye 20 dakika müdahale edilmediğini yazarken Milat gazetesi bu sürenin yarım saat (30 dakika) olduğunu vurgulamıştır. Haber metninde ise “ABD'nin ve Batı'nın köpeği Mısır darbecisi Sisi'nin Muhammed Mursi'yi zehirleyerek kasten öldürdüğüne ilişkin iddialar güçleniyor." denilirken Mursi'nin kafes içinde tutulduğuna dikkat çekilmiştir. 21 Haziran 2019 tarihli sayısında "Unutturmayacağız" sürmanşetini atan gazete, Erdoğan'ın konuyla ilgili açıklamalarına ve "Demokrasi katliamı" ile "BM gündeme almalı" ara başlıklarına yer vermiştir. "İ̧şkence görüyordu" başlıklı başka bir haberde ise, Milat, çok sayıda uluslararası kuruluşun Mursi'nin kasitlı ihmal sonucu öldüğünü ve Mursi’ye sistematik işkence uygulandığını açıkladığını belirtmiştir. 22 Haziran 2019 tarihli sayısında gazete, "Yavaşça öldürüldü” başlıklı haberinde kaynak göstererek Mursi'nin öldürüldüğüne dair birçok işaretin olduğunu, Mursi'nin ilaçlar, sağlıklı beslenmeden ve uygun bir yerde barındırılmaktan mahrum bırakılarak 6 yıl boyunca yavaşça öldürüldüğünü yani sistematik işkence ile katledildiği söylemini üretmiştir.

Milli Gazete, 18 Haziran 2019 tarihli sayısında siyah-beyaz yayınlanarak Mursi'nin ölümü dolayısıyla yasta olduğunu vurgulamaya çalışmıştır. Bu sayıda "Utan ey ikiyüzlü dünya Mursi şehid oldu" diye seslenen gazete, haberin spotunda ise, "Misır zindanlarındaki direniş destanını sürdüren Mısır Cumhurbaşkanı Muhammed Mursi, mahkeme salonunda şehadete yürüdü." ifadelerini kullanarak Mursi'nin ölümüne bir 
kahramanlık, destansallık katmaya çalışmıştır. Gazete, haber metninde de "5 yılı aşkın süredir Mısır zindanlarında tutuklu bulunan Muhammed Mursi, 'Anayasamız Kur'an'dır' açıklamasıyla Müslümanların gurur kaynağı olmuştu." şeklinde benzer ifadelere yer vermiştir. Mursi'nin oğlunun bir açıklamasına yer veren gazete, "Babam her an şehit olabilir' demişti” ifadesini başlığına taşıyarak bu sonun önceden tahmin edildiğinin altını çizmiştir.

Görsel 10. Milli Gazete, 18 Haziran 2019

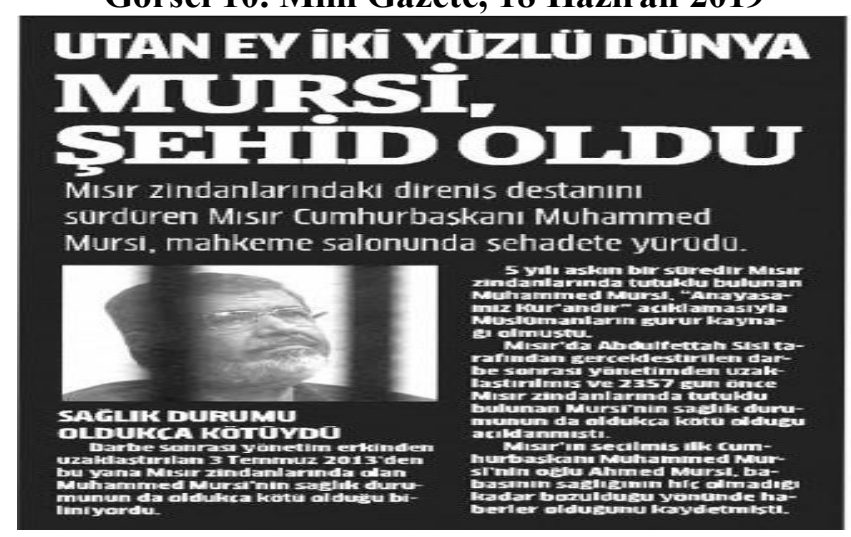

19 Haziran 2019 tarihli sayısında öznel bir söylemle ve kocaman puntolarla "Şehadetin kutlu olsun" manşetini kullanan Milli Gazete, haberin spotunda "Misır'ın ilk seçilmiş Cumhurbaşkanı Muhammed Mursi'nin zalimlere boyun eğmeyen 6 yıl devam eden tutsaklığı, mahkeme salonunda şehadet şerbeti içmesiyle son buldu. Mursi'nin Mevla'ya yürümesi ümmet coğrafyasında büyük üzüntüye sebep olurken, Türkiye'den ise 7'den 70'e milyonlarca vatandaş üzüntülerini paylaştı." ifadelerine yer vermiştir. Gazete, aynı sayfada "İslam ümmetine sabırlar diliyorum", "Sözümüzde duracağız", "AGD, İstanbul ve Ankara'da konsolosluklara akın etti", "Tavizsiz duruşu ile tarihe geçti", "Şehit Mursi'ye Allah'tan rahmet diliyorum", "İslam dünyasına başsağlığı dileriz", "81 il şehit Mursi için saf tuttu" ve "Şehit Mursi için 'Kardeşim sen özgürsün"” başlıklı haberlere yer vermiştir. Gazetedeki haberlerin tamamında Mursi'nin duruşunu destekleyen ve onun ölümünden üzüntü duyulan ifadelere yer verilmiştir.

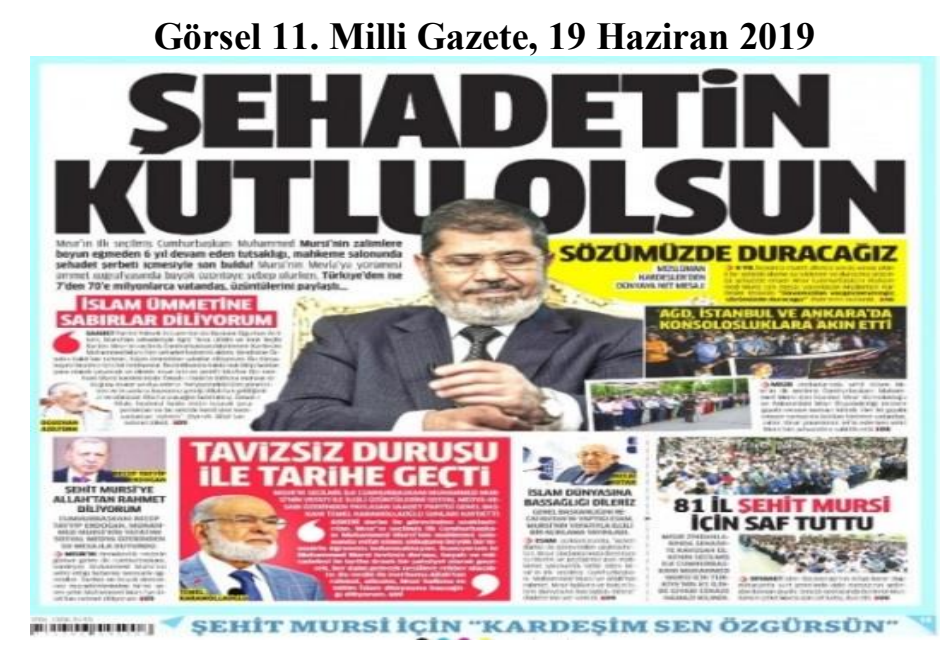

20 Haziran 2019 tarihli sayısında Milli Gazete, "Yere düşmüş 20 dakika müdahale edilmemiş" başlıklı haberi kullanmıştır. Haberin görseli olarak parmaklıklar ardındaki Mursi'nin fotoğrafını kullanan gazete görselin üzerinde ise, "Cennetin yeni yolcusuna!" başlığıyla birlikte "Mursi dostum, selam et 'Bedrin arslanlarına...' Hiç itibar etmedin kölelerin şahına! Tam bir cihattı cehdin. Uhutça cedelleştin... Baş eğmedin Siyonist denilen kaltabana" ifadeleri yer almıştır. Bu ifadelerle gazetenin Mursi'yi bir şehit olarak 
cihat havasında uğurladığı görülmüştür. 21 Haziran 2019 tarihli sayısında gazete, "Filistin Mursi'nin kalbindeydi" başlıklı habere yer verilerek tıpkı Erdoğan gibi Mursi'nin de Filistin konusundaki duyarlılığı vurgulanmıştır.

Ortadoğu gazetesi, 19 Haziran 2019 tarihli sayısında "Ölüsünden bile korktular" başlığını kullanarak Mursi'nin apar topar defnedildiğini bildirmiştir. Mursi için 'Mısır'ın demokratik yöntemlerle seçilmiş ilk cumhurbaşkanı" nitelemesi kullanılırken, Türkiye'de Mursi için gıyabi cenaze namazı kılındığı bilgisini vermiştir. Mursi'nin fotoğrafına yer vermeyen gazete, 20 Haziran 2019 tarihli sayısında Erdoğan'ın "Mursi ölmedi öldürüldü" şeklindeki ifadelerini başlığına taşımıştır.

Sözcü gazetesi, 18 Haziran 2019 tarihli sayısında "Mursi mahkeme salonunda öldü” başlıklı küçük bir haberle olayı duyurmuştur. Mursi için "Mısır'ın darbeyle devrilen lideri” nitelemesi yapan Sözcü, Erdoğan'ın Mursi'ye "şehit" dediğini ve yakınlarına başsağlığı dilediğini yazmıştır. Gazete, konuyla ilgili çok fazla habere yer vermemiştir.

Star gazetesi, 18 Haziran 2019 tarihli sayısında "Mısır'ın seçilmiş lideri Mursi Hakk'a yürüdü” diyerek Muhammed Mursi'nin ölümünü duyurmuştur. Mursi için "seçilmiş ilk cumhurbaşkanı" nitelemesini kullanan gazete, haber metninde Mursi'nin Sisi'nin darbesiyle görevinden uzaklaştırıldığını, onurlu ve dik bir duruşa sahip olduğundan bahsetmiştir. Cunta yönetiminin Mursi'ye zulmettiğinin altını çizen gazete, Mursi'nin darbe sonrasındaki ilk açıklamasında yer alan "Hakkı ve hukuku korumanın bedelini gerekirse hayatımla öderim" ifadelerini hatırlatmıştır. Gazete bu haberde Mursi'nin parmaklıklar ardındaki fotoğrafını kullanmıştır. Bu haberin yan tarafinda Erdoğan'ın "Tarih zalimleri unutmayacak" şeklindeki ifadelerine yer veren gazete, ayrıca Erdoğan'ın Mursi için "şehit" dediğini yazmıştır.

Görsel 12. Star, 18 Haziran 2019

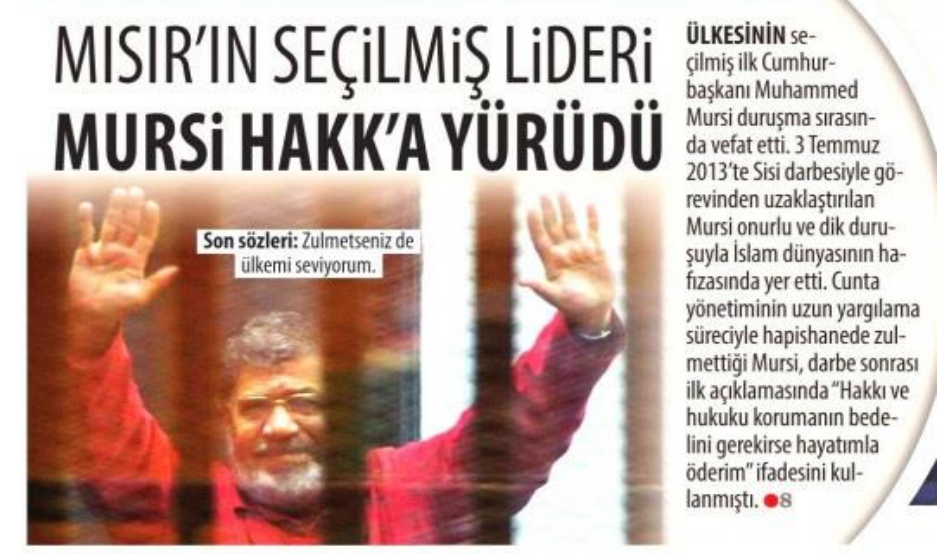

19 Haziran 2019 tarihli sayısında Erdoğan'ın konuyla ilgili açıklamalarına yer veren Star, Erdoğan'ın Mursi'ye çektirilen eziyetleri Batı dünyasının seyrettiğini, Mursi'nin şehadetinin normal ölüm olmadığını "Zalimler için yaşasın cehennem" başlıklı haberle vermiştir. Aynı tarihli sayısında "Ölüsünden bile korktular" başlığıyla olayı manşetine taşıyan gazete, spotunda "İşkence altında 6 yıl cezaevinde tutulan Mısır'ın seçilmiş ilk Cumhurbaşkanı Mursi'nin ölümü bile darbeci Sisi'yi korkutmaya yetti. Cunta yönetimi cenazesini sabaha karşı apar topar defnetti." ifadelerini kullanmıştır. Müslüman Kardeşler Teşkilatı'nın "Kasten öldürüldü” şeklindeki sözlerini örnek gösteren gazete, Mursi'nin ölümünün araştırılması gerektiği çağrısında bulunmuştur. Aynı sayıda konuyla ilgili yer alan "Darbe mahkemesi uyarıyı dikkate almadı" başlıklı haberle mahkemeyi adaletli bulmadığını, "Türkiye gıyabi cenaze namazını kıldı" şeklindeki bir başka haberle 
ise, tüm Türkiye'nin olaydan üzüntü duyduğunu, Mursi'yi sevip saydığını vurgulamaya çalışmışıtır.

Görsel 13. Star, 19 Haziran 2019

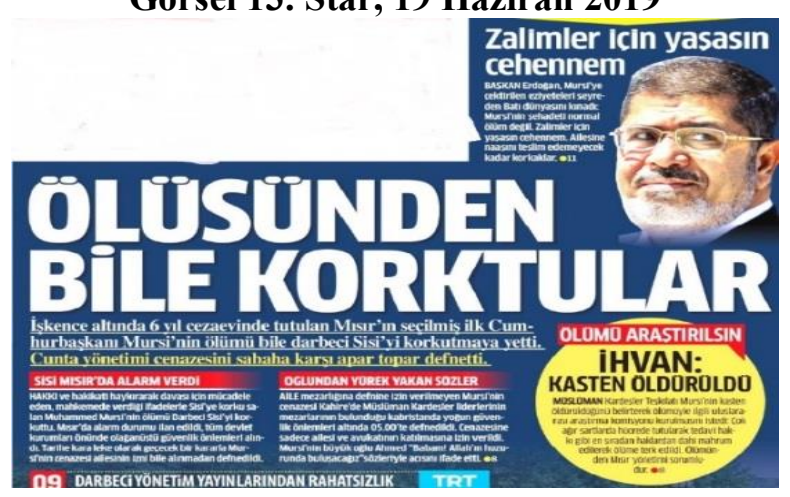

Mursi'nin ölümünün araştırılması çağrısında bulunan Star, 20 Haziran 2019 tarihli sayısında net bir ifadeyle "Evet, Mursi'yi öldürmüşler" başlığını atarak iddiadan öteye gitmiştir. Başlıktaki ifade her ne kadar sanki yetkili bir ağızdan alınmış gibi gösterilmiş olsa da haber metnine bakıldığında Mursi'nin mahkeme salonunda baygınlık geçirdikten sonra 30 dakika (kimi gazetelere göre 20 dakika) ambülansın çağrılmamış olmasından bahsedildiği görülmektedir. Gazetenin başlıktaki söylemi ise bu durumu onayladığını desteklemektedir.

Türkgün gazetesi, 19 Haziran 2019 tarihli sayısında "Mursi toprağa verildi" başlığıyla konuya değinmiştir. Türkgün gazetesi de Mursi'nin demokratik yollarla seçilmiş olduğuna vurgu yapmıştır. Mursi'nin sessiz bir törenle toprağa verildiğini ifade eden gazete, Erdoğan'ın Mursi için “Şehidimize Allah'tan rahmet diliyorum” şeklindeki ifadelerine yer vermiştir. Gazete haberle ilgili olarak Mursi'yi uğurlayan kalabalıkla birlikte elindeki Mursi'nin fotoğrafını havaya kaldıran bir çocuğun fotoğrafını kullanmıştır. 20 Haziran 2019 tarihli sayısında gazete, "Mursi'yi ölüme terk ettiler" başlıklı haberle mahkeme salonunda baygınlık geçiren Mursi'ye geç müdahale edildiğini belirtmiştir.

Türkiye gazetesi, 18 Haziran 2019 tarihli sayısında "Misır demokrasi kahramanının şüpheli ölümü” üst başlığını ve "Mursi şehit düştü” ana başlığını kullanarak Mursi'nin ölümünden üzüntü duyduğunu göstermiştir. Sisi' yi “darbeci” olarak nitelendiren gazete, Sisi'nin Mursi'nin cenazesini kaçırdığını ve olağanüstü hal ilan ettiğini yazmıştır. Mursi'nin Mısır'ın demokratik yollarla seçilmiş ilk cumhurbaşkanı olduğunun altını çizen gazete, Erdoğan'ın Mursi'nin şehit olduğu şeklindeki sözlerini satırlarına taşımıştır. 19 Haziran 2019 tarihli sayısında "Yalnız gitti milyonlar namazını kıldı" başlığını kullanan gazete, Türkiye'de Mursi için kılınan gıyabi cenaze namazlarının yanı sıra Sisi'nin Mursi'nin ölümünden keyif aldığını yazmıştır. 20 Haziran 2019 tarihli sayısında Mursi'nin parmaklıklar ardındaki fotoğrafının üzerinde kırmızı zemin üzerinde "Resmen cinayet" ibaresine yer veren gazete, haberin başlı̆̆ seçerken haberde Mursi'nin baygınlığı sonrasında kendisine 20 dakika müdahale edilmediğini yazmıştır. 
Görsel 14. Türkiye, 18 Haziran 2019

MISIR DEMOKRASI KAHRAMANININ ŞÜPHELİ ÖLÜMÜ Mursi șehit düștï

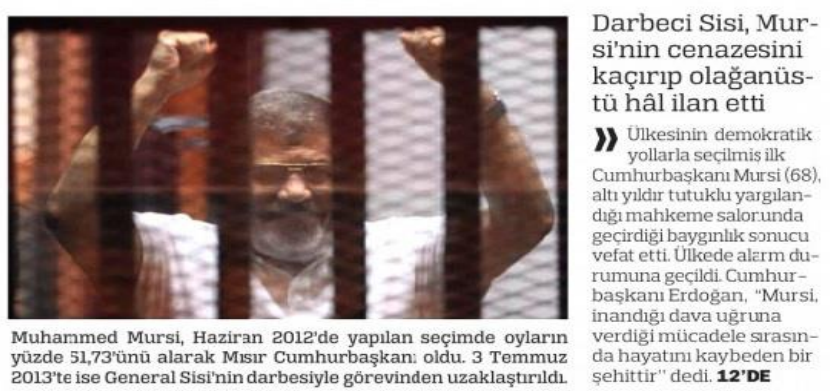

Yeni Akit gazetesi, 18 Haziran 2019 tarihli sayısında konuyla ilgili "Mursi, duruşma salonunda Hakk'a yürüdü" üst başlığını ve "Esaretten şehadete" başlığını kullanmıştır. Gazete haber metninde, Mursi'nin hapishanede kaldığı zaman dilimi için 6 yıl ibaresini değil de 2 bin 357 gün ibaresini kullanmış ve bu süre zarfında Mursi'nin zulüm gördüğünü yazmıştır. Mursi’nin “Anayasamız Kur'an'dır” ve "Gelecek nesiller bizler için 'Onlar adamdı' diyecekler" şeklindeki sözlerini hatırlatan gazete, Erdoğan'ın “Şehidimize Allah'tan rahmet diliyorum" şeklindeki ifadelerini başlığa taşımıştır. 19 Haziran 2019 tarihli sayısında "İslam dünyası Mursi için ayakta" üst başlığını kullanan gazete, "Ümmet O’nu kalbine gömdü” başlığını manşetten vermiştir. Gazete haberin spotunda ise, “Çağımızın firavunlarına karşı verdiği destansı mücadele ile gönüllere taht kuran Mısır'ın seçilmiş ilk Cumhurbaşkanı Muhammed Mursi'nin duruşma salonundaki vefatı, İslam dünyasını yasa boğdu. Türkiye'nin 81 ilinde gıyabi cenaze namazları kılınırken, Siyonistlerin kuklası Suudlar ve BAE (Birleşik Arap Emirlikleri) haricindeki bütün İslam ülkelerinde Sisi'ye lanet, Mursi'ye rahmet mesajları yağdı. Firavun Sisi, Mursi'yi sabahın erken saatinde gizlice defnettirirken, ümmet O'nu kalbine gömdü." ifadelerine yer vermiştir. Gazete Sisi için "firavun" nitelemesini kullanmıştır. Buradaki firavun kelimesi "zalim kişi, zulmeden kişi”" anlamındadır. "Firavun, kahramanın cenazesinden bile korktu!” ifadesinde Sisi'nin Firavun, Mursi'nin ise kahraman olduğu şeklinde bir söylem üretilmiştir. Haberin metninde ise, "ABD ve Siyonist tasmalı darbeci Sisi, özgürlük kahramanı Mursi'nin cenazesinden korktu." derken Sisi köpeğe benzetilmiştir. Türkiye'deki gıyabi cenaze namazından da bahsedilen haberde "Onun yolunda nesiller yetiştireceğiz" ve "Firavun'a lanet, Mursi için dua yağdı" ara başlıkları dikkat çekmiştir. "Batı sessiz, kukla Suud'dan alçaklık!" başlıklı haberde Batı ve Suudi Arabistan Mursi'ye karşı olan tavırlarından dolayı eleştirilmiştir.

Görsel 15. Yeni Akit, 19 Haziran 2019

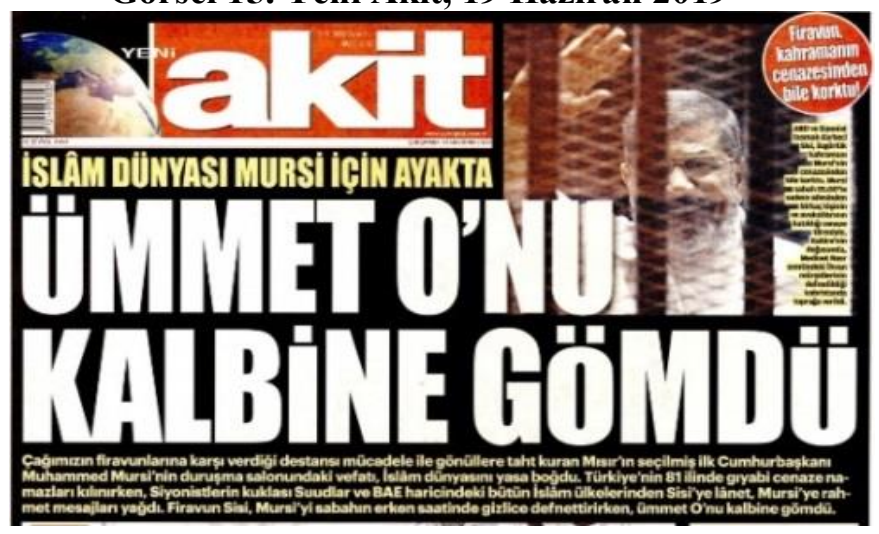


20 Haziran 2019 tarihli sayısında Yeni Akit, Mursi'nin duruşma salonunda baygınlık geçirmesinin ardından ona uzun süre müdahale edilmemiş olmasıyla ilgili "Bile bile ölüme terk ettiler" başlığını atarak sonucu eleştirmiştir.

Yeni Asya gazetesi, 19 Haziran 2019 tarihli sayısında Mursi’nin ölüm haberiyle ilgili "Kaybeden Mısır oldu" manşetini atarak bu ölümden Mısır'ın zararlı çıktığını ifade etmiştir. Gazete, haberin spotunda Mursi'nin seçildiği tarihin yıldönümünde vefat etmesine dikkati çekmiştir. Haber metninde ise gazete, Arap Baharı'nın Mısır için iyi sonuçlar doğurmadığını anlatmıştır. "Hayatıyla ödedi" başlıklı bir başka haberde gazete, Mısır'ın demokratik yöntemlerle seçilmiş ilk Cumhurbaşkanı Muhammed Mursi'nin darbe sonrasında yaptığı ilk açıklamada "Hakkı ve hukuku korumanın bedelini gerekirse hayatımla öderim" dediğini hatırlatmıştır. "Kasten öldürüldü” ve "Karadaği: Ölmedi, yavaş yavaş öldürüldü" başlıklı haberlerde Mursi'nin öldürüldüğüne dikkat çekilirken "BM soruştursun" başlıklı başka bir haberde ise, Mursi'nin ölümünün araştırılması çağrısında bulunulmuştur. "Mısır demokrasisinin budanmış yolu" başlıklı haberde ise İspanya'nın El Pais gazetesinde konuyla ilgili çıkmış olan yazıya dikkat çekilmiştir.

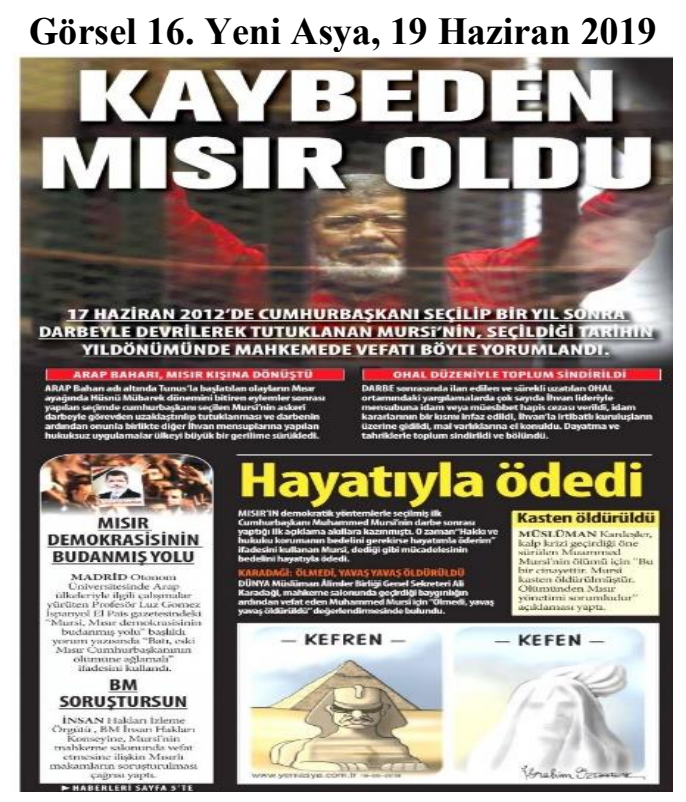

20 Haziran 2019 tarihli sayısında "Tarih bu zulmü unutmayacak" manşetini atan gazete, konuyla ilgili diğer bir haberde "Ölüme terk ettiler” başlığını kullanmış, Mursi'nin duruşma salonunda bayılmasından sonra kendine müdahale edilmemesine dikkatleri çekmiştir. Böylelikle ölümle sonuçlanan olayı "zulüm” olarak nitelendirerek öznel bir söylem üretmiştir. Bir başka haberde, Mursi'nin ölümünün sorumluluğu Sisi’ye atılırken diğer bir haberde ise ölümünün ardından ilk eylemin Mursi'nin köyünde olduğundan bahsedilmiştir. 21 Haziran 2019 tarihli sayısındaki haberde ise gazete, Mursi için tıbbi soruşturmanın açılması çağrısında bulunmuştur.

Görsel 17. Yeni Asya, 20 Haziran 2019

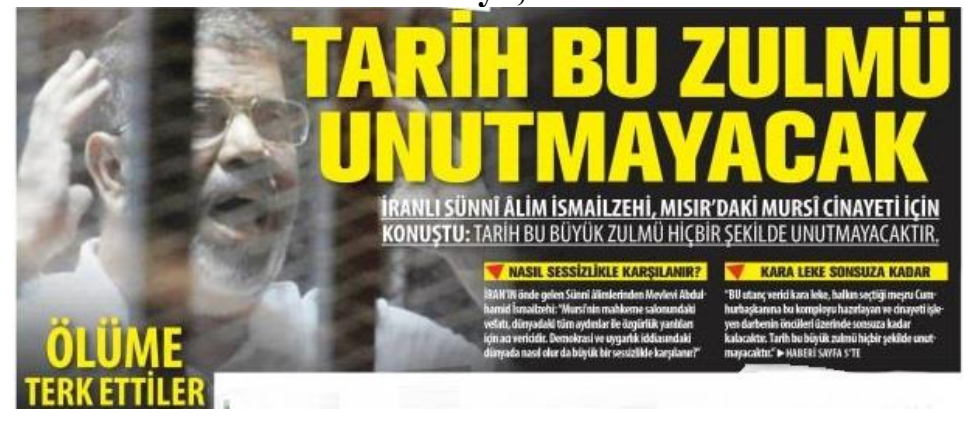


Yeni Birlik gazetesi, 18 Haziran 2019 tarihli sayısında ölüm haberini "Mursi şehid oldu" başlığıyla sürmanşetten duyurmuştur. Fotoğrafta ise Mursi'nin parmaklıklar arkasındaki görüntüsü kullanılırken gazetenin "Mısır'ın demokratik yöntemlerle seçilmiş ilk cumhurbaşkanı" nitelemesi dikkat çekmiştir. Gazete spotta Erdoğan'ın Mursi için kullandığı "Mursi kardeşimize, şehidimize Allah'tan rahmet diliyorum." şeklindeki ifadelerine de yer vermiştir. Ölüm anıyla ilgili bilgi veren gazete ayrıca Mursi'nin ölümünün ardından gelen açıklamalarla birlikte Türkiye'de gıyabi cenaze namazı kılınacağının bilgisini paylaşmıştır.

Görsel 18. Yeni Birlik, 18 Haziran 2019

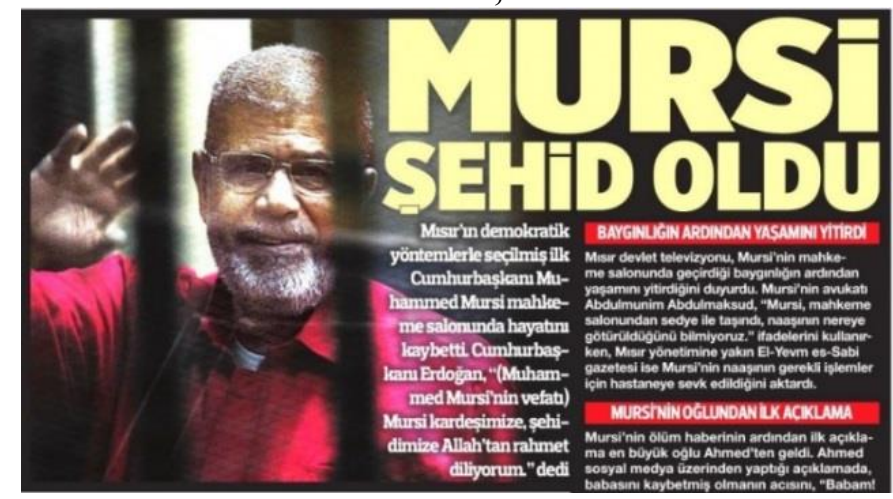

19 Haziran 2019 tarihli sayısında gazete, Mursi'nin yaşamını yitirmesiyle ilgili Erdoğan'ın ölümünü normal bir ölüm olmadığına inandığıyla ilgili açıklamasına yer vermiştir. Yeni Birlik, 20 Haziran 2019 tarihli sayısındaki "Mısır yargılanmalı" başlıklı haberde Erdoğan'ın Mursi'nin öldürüldüğü ve sürecin takipçisi olacaklarıyla ilgili açıklamasını kullanmıştır.

İncelemenin yapıldığı zaman aralığıyla ilgili sadece bir sayısında küçük bir haberle yer veren Yeni Çăg gazetesi, 18 Haziran 2019 tarihli sayısında ölüm haberini "Mursi, mahkeme salonunda hayatını kaybetti” başlığını kullanarak duyurmuştur. Gazete, Mursi için "Mısır'ın demokratik yollarla seçilmiş ilk cumhurbaşkanı” nitelemesine yer vermiş ancak Mursi'yi "şehit”" olarak nitelendirmemiş olması dikkat çekmiştir.

Yeni Söz gazetesi, 19 Haziran 2019 tarihli sayısında Mursi'nin ölümünü "Firavunların son kurbanı" başlığı ve "Son devrin firavunları tarafindan darbeyle görevinden uzaklaştırılan Mısır'ın demokratik yollarla seçilmiş ilk Cumhurbaşkanı Muhammed Mursi, mahkeme salonunda şehit oldu." spotuyla ve "şehit" söylemiyle manşetten duyurmuştur. Gazete fotoğraf olarak haberinde Mursi'nin bir camide ön saflarda namaz kılarken ki fotoğrafına yer vermiştir. Gazete, bu fotoğrafla nüfusunun çoğunluğu Müslüman olan bir ülkenin duygularına seslenmeye çalışmıştır. Gazete haberde "Duruşma salonunda hayatını kaybetti" ve "Mursi gizlice defnedildi" ara başlıklarına da yer vererek Mursi için "şehit" ifadesini kullanmıştır. Bir başka haberde ise, "Mursi ölmedi yavaş yavaş öldürüldü” başlığıyla Mursi'nin ölümünün eceliyle olmadığını kaynak göstererek ifade etmiştir. Gazete "Mursi'nin ölümü Arap liderlerinin alnında bir leke" başlıklı habere yer vererek Arap liderleri suçlanmıştır. 20 Haziran 2019 tarihli sayısında Yeni Söz gazetesi, "Mursi'ye 20 dakika müdahale etmemiş̧ler" başlıklı haberde müdahale edilmeyerek Mursi’nin bilinçli bir şekilde ölüme terk edildiğini ima etmiştir. 


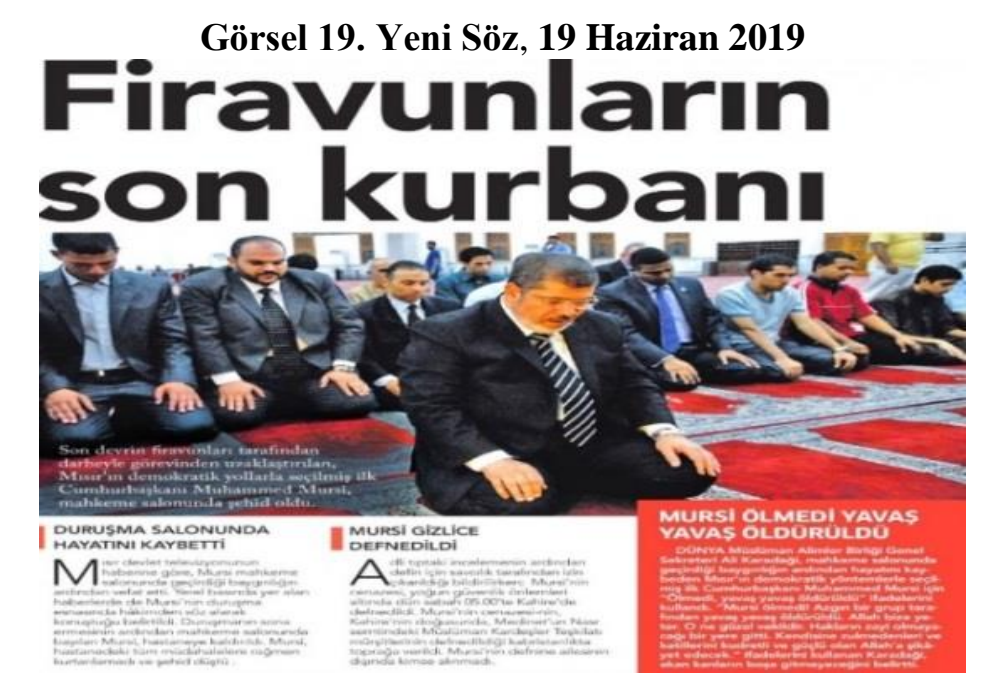

Yeni Şafak gazetesi, 18 Haziran 2019 tarihli sayısında sürmanşette siyah zemin üzerinde "Dünya böyle zulüm görmedi Mursi'yi mahkeme salonunda öldürdü" başlığını kullanarak Mursi'nin ölümünü duyurmuştur. Gazete haberin spotunda ise, Mursi'nin Mısır'ın seçilmiş ilk cumhurbaşkanı olduğunu, 5 yıldan fazla süredir Mısır zindanlarında tutulduğunu, 2357 gündür direniş destanını sürdürdüğünün yanı sıra duruşmalara zorla çıkarıldığını belirtmiştir. Mısır Cumhurbaşkanı Sisi'nin fotoğrafının yan tarafında "Mısır'ın seri katili" ifadesini kullanan gazete, bu ölümden de Sisi'nin sorumlu olduğu imasını çizmeye çalışmıştır. Mursi'nin fotoğrafının üzerinde ise, "Büyük şehit" ifadesine yer veren gazete, Mursi'nin ölümünün sorumluluğunu ABD, İsrail, AB ülkeleri, Suudi Arabistan, Birleşik Arap Emirlikleri ve Sisi'ye yüklemiştir. Haberin ara başlığında “Şehidimize Allah'tan rahmet diliyorum" diyerek Erdoğan'ın ifadelerine yer veren gazete, ayrıca Erdoğan'ın Mursi'nin şehit, Sisi'nin ise, zalim olduğuyla ilgili açıklamasını da kullanmıştır.

Görsel 20. Yeni Şafak, 18 Haziran 2019

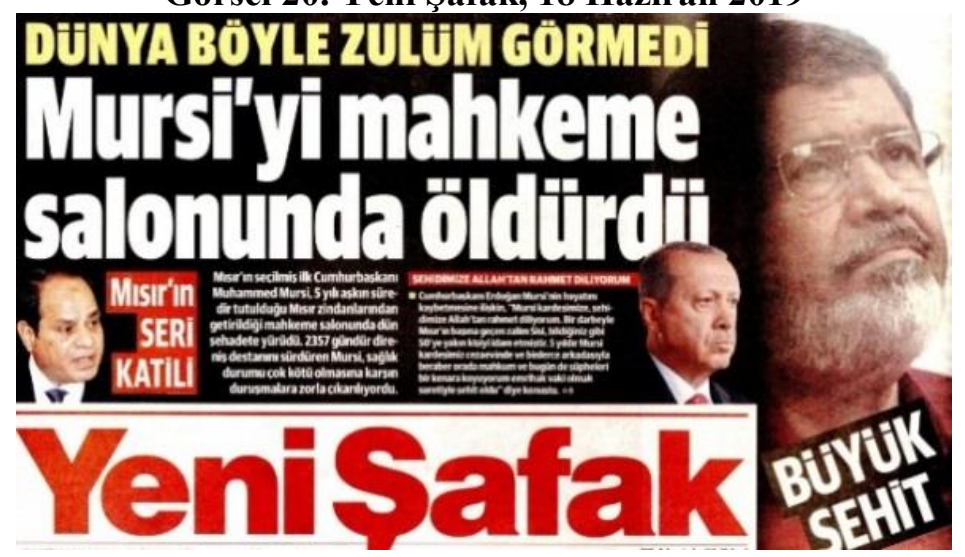

19 Haziran 2019 tarihli sayısında Yeni Şafak, "Ölüsü bile korkuttu” başlığını sürmanşetten vermiştir. "Darbeci Sisi rejiminin şehit ettiği ülkenin seçilmiş ilk Cumhurbaşkanı Mursi'nin cenazesi bile cunta yönetimini korkuttu.” spotunu kullanan gazete, ayrıca Mursi'nin 5 yıldır zindanlarda ağır psikolojik ve fiziki işkenceye dayanamayarak mahkemede hayatını kaybettiğini yazmıştır. Başka bir haberde Türkiye'nin 81 ilinde gıyabi cenaze namazının kılındığını belirten gazete, Mursi'nin sabaha doğru gizlice gömüldügünün altını çizmiştir. Gazete, ayrıca Mursi’ye otopsi yapılmadığı, Mursi'nin iki yıldır sağlığının iyi olmadığ alınmayarak tıbbi işkenceye maruz bırakıldığını yazmıştır. Aynı sayfada yer alan "Seçildiği gün katlettiler" başlıklı haberde Mursi'nin 17 Haziran 2012'deki 
cumhurbaşkanlığ seçimlerinde göreve geldiği hatırlatılmış ve cumhurbaşkanı seçilmiş olduğu günde şehit edilmiş olmasının özel bir anlamı olduğunu Mursi'nin kabinesinde yer almış olan Enformasyon Bakanı Selahaddin Abdulmaksut'un ağzından belirtilmiştir. Gazete, "Karanlıkta kalan saatler" başlı̆̆ıyla verdiği haberde Mursi'nin, mahkemeden alınarak hastaneye götürüldüğü ve defnedildiği süreçte karanlıkta kalan yaklaşık 12 saat sonunda cenazenin apar topar defnedilmesini öldürüldüğü kuşkularını arttırdığına dikkat çekmiştir.

Görsel 21. Yeni Şafak, 19 Haziran 2019

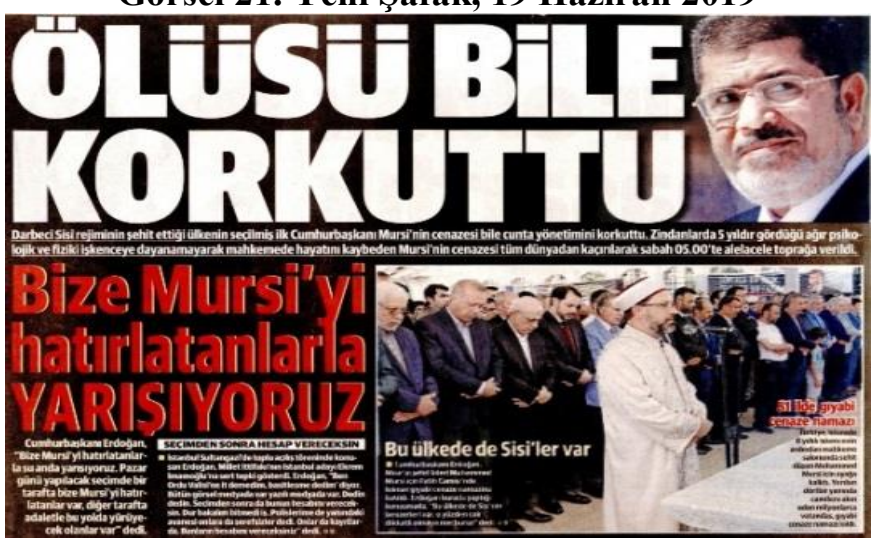

Yeni Şafak, 20 Haziran 2019 tarihli sayısında “Ölmesini beklediler” üst başlığını ve "20 dakika can çekişti” başlığını kullanılarak Mursi için mahkeme salonunda hiçbir müdahalenin yapılmadığını yazmıştır. 22 Haziran 2019 tarihli sayısında "Başın sağ olsun diyeni tutukluyorlar" başlığını kullanan Yeni Şafak, haber metninde Sisi'nin Mursi'nin yakınlarına zulmetmeyi sürdügünü, başsağlığına gidenleri tutuklattığını yazmıştır. Gazete haberde ayrıca Mursi'nin tutukluluk döneminde maruz kaldığı işkencelere de yer vermiştir.

Tablo 1. Gazetelerin Yayın Çizgilerine Göre Mursi’nin Ölümünü Söylemsel Üretim Şekilleri

\begin{tabular}{|c|c|c|c|c|c|}
\hline Yayın Çizgisi & Gazete & $\begin{array}{c}\text { Öldü/ Hayatını } \\
\text { Kaybetti }\end{array}$ & $\begin{array}{c}\text { Şehit/ Hakka } \\
\text { Yürüdü }\end{array}$ & $\begin{array}{c}\text { Seçilmiş } \\
\text { Cumhurbaşkanı }\end{array}$ & $\begin{array}{l}\text { Darbeyle Devrilen/ } \\
\text { Uzaklaştırılan Lider }\end{array}$ \\
\hline \multirow{4}{*}{ Sol } & Cumhuriyet & $\sqrt{ }$ & & & \\
\hline & Sözcü & $\sqrt{ }$ & & & $\sqrt{ }$ \\
\hline & Evrensel & $\sqrt{ }$ & & & \\
\hline & Birgün & $\sqrt{ }$ & & $\sqrt{ }$ & \\
\hline \multirow{13}{*}{$\begin{array}{c}\text { Muhafazakâr } \\
\text { Sağ }\end{array}$} & Yeni Akit & & $\sqrt{ }$ & $\sqrt{ }$ & \\
\hline & Yeni Asya & $\sqrt{ }$ & & $\sqrt{ }$ & $\sqrt{ }$ \\
\hline & Yeni Şafak & & $\sqrt{ }$ & $\sqrt{ }$ & \\
\hline & Milli Gazete & & $\sqrt{ }$ & $\sqrt{ }$ & \\
\hline & Diriliş Postas1 & & $\sqrt{ }$ & $\sqrt{ }$ & \\
\hline & Yeni Söz & & $\sqrt{ }$ & $\sqrt{ }$ & $\sqrt{ }$ \\
\hline & Milat & & $\sqrt{ }$ & $\sqrt{ }$ & $\sqrt{ }$ \\
\hline & Türkiye & & $\sqrt{ }$ & $\sqrt{ }$ & \\
\hline & Yeni Birlik & & $\sqrt{ }$ & $\sqrt{ }$ & \\
\hline & Akşam & & $\sqrt{ }$ & $\sqrt{ }$ & $\sqrt{ }$ \\
\hline & Güneş & & $\sqrt{ }$ & $\sqrt{ }$ & \\
\hline & Star & & $\sqrt{ }$ & $\sqrt{ }$ & $\sqrt{ }$ \\
\hline & Karar & & $\sqrt{ }$ & $\sqrt{ }$ & \\
\hline \multirow{4}{*}{ Milliyetçi Sağ } & Yeni Çă̆ & $\sqrt{ }$ & & $\sqrt{ }$ & \\
\hline & Türkgün & & & $\sqrt{ }$ & \\
\hline & Ortadoğu & & & $\sqrt{ }$ & \\
\hline & Anayurt & $\sqrt{ }$ & & & $\sqrt{ }$ \\
\hline
\end{tabular}

Analizin yapıldığı süre içerisinde Mursi'nin ölümüyle ilgili Aydınlık, Korkusuz, Yeni Mesaj ve Yurt gazeteleri birinci sayfalarında konuyu hiç haberleştirmemiştir. Bu nedenle bu gazetelere tabloda yer verilmemiştir. Söylem analizinde haber metinlerinde kullanılan her kelimeye anlam yükleme söz konusudur. Dolayısıyla Mursi'nin ölümü 
üzerine gazetelerin "şehit oldu" şeklindeki kullanımı ile "öldü ya da hayatını kaybetti" şeklindeki kullanımı arasında söylemsel açıdan farklılık bulunmaktadır. Tabloda incelenen gazetelerden 7'si “Öldü/ Hayatını Kaybetti" kelimelerini kullanırken 12 gazete ise "Şehit/ Hakka Yürüdü” kelimelerini tercih etmiştir. Bunun yanı sıra söz konusu gazetelerden 17'si "Seçilmiş Cumhurbaşkanı" ifadesini seçerken 7 gazete ise "Darbeyle Devrilen/ Uzaklaştırllan Lider" vurgusuna dikkat çekmiştir.

Gazetelerin sahip oldukları ideoloji ya da yayın çizgilerine göre bir değerlendirme yapıldığında ise, sol çizgide yer alıp konuyu işleyen gazetelerin Mursi'nin ölümünü duyururken "öldü ya da hayatını kaybetti" söylemini tercih ederken "şehit ya da hakka yürüdü" söylemini hiç kullanmadıkları görülmüştür. Aksine sol çizgide yer alan gazetelerin bu kullanımı tercih edenleri eleştirdikleri bulgulanmıştır. Bunun yanı sıra "seçilmiş cumhurbaşkanı" ifadesini sadece Sözcü gazetesi tercih ederken "darbeyle devrilen veya uzaklaştırılan lider" söylemini sol çizgide yer alan gazetelerden sadece Birgün kullanmıştır.

Muhafazakâr sağ çizgide yer alan gazetelerin Mursi’nin ölümünü önemli derecede işledikleri görülmüştür. Bu çizgide yer alıp konuyu birinci sayfasında işlemeyen tek gazete, Yeni Mesaj olmuştur. Bu çizgide yer alan gazetelerden sadece Yeni Asya gazetesi "öldü ya da hayatını kaybetti" söylemini tercih ederken "şehit ya da hakka yürüdü" söylemini geriye kalan tüm gazetelerin kullandığı görülmüştür. Bu sonuç muhafazakâr sağ çizgide yer alan gazetelerin Mursi'nin ölümüne dini bir anlam yüklediklerini ortaya koymaktadır. Bu çizgideki gazetelerin tamamı "seçilmiş cumhurbaşkanı" ifadesine vurgu yaparken Yeni Asya, Yeni Söz, Milat, Akşam ve Star gazeteleri "darbeyle devrilen veya uzaklaştırılan lider" söylemini yeniden üreterek hatırlatmada bulunmuştur.

Milliyetçi sağ çizgide yer alan gazetelerden Yeni Çă̆ ve Anayurt "öldü ya da hayatını kaybetti" söylemini kullanırken bu gazetelerden hiçbiri "şehit ya da hakka yürüdü" ifadesini konuyla ilgili haberlerde tercih etmemiştir. Bu durum bu çizgide yer alan gazetelerin olaya dini bir anlam yüklemediklerini, normal bir ölüm şeklinde yansıttıklarını ortaya koymaktadır. Sadece Anayurt gazetesi "darbeyle devrilen veya uzaklaştırılan lider" söylemini kullanırken Yeni Çağ, Türkgün ve Ortadoğu gazeteleri ise "seçilmiş cumhurbaşkanı" ifadesinin altını çizerek demokratik seçime işaret etmiş̧tir.

\section{Sonuç}

17 Haziran'da duruşma salonunda hayatını kaybeden Mısır'ın eski lideri Muhammed Mursi'nin ölümünün Türk ulusal basınında sunumunun konu edildiği çalı̧̧mada incelenen 25 ulusal gazeteden Aydınlık, Korkusuz, Yeni Mesaj ve Yurt gazetelerinin, analizin yapıldığı süre zarfında, birinci sayfalarında konuyla ilgili herhangi bir habere yer vermedikleri görülmüştür. Konuyu haberlerinde yer verecek kadar değerli bulmayan bu gazeteler dışındaki gazetelerde konunun işlendiği görülmekle birlikte gazetelerin yayın çizgilerine bağlı olarak konuya yaklaşım tarzlarında farklıı̆ı̆ın söz konusu olduğu bulgulanmıştır.

Genel olarak sol çizgide yer alan gazeteler konuya çok fazla ilgi göstermemiş, konuyu birinci sayfalarında az derecede işlemiş ve Mursi'nin ölümünü normal bir ölüm olarak göstermiş̧tir. Mahkeme salonunda bayıldıktan sonra ölen Muhammed Mursi için "Mısır'ın devrik cumhurbaşkanı", "Müslüman Kardeşler Örgütü üyesi", "eski Mısır Cumhurbaşkanı", "Mısır'ın darbeyle devrilen lideri”" gibi nitelemeler kullanmışlardır. Bu gazeteler, iktidar partisi yanlısı gazetelerin aksine Mursi'nin demokratik yolla seçilen ilk cumhurbaşkanı olduğundan hiç bahsetmemişlerdir. Söz konusu gazeteler, Cumhurbaşkanı Erdoğan'ın Mursi'nin şehit olduğunu söylemesini gündemlerine almış ve durumu dolaylı yoldan eleştirmişlerdir. Bunun yanı sıra iktidar yanlısı gazetelerin de böyle bir yaklaşım 
içerisinde olmalarını eleştirerek dolaylı olarak "Mursi'nin şehit olmadığını" yansıtmaya çalışmışlardır. Sol çizgideki gazetelerin Mursi'nin ölümü üzerinden eleştirdiği taraf, AK Parti'nin tavrı olmuştur.

Sağ çizgide yer alan ya da iktidar partisi yanlısı gazeteler değerlendirildiğinde ise bu gazetelerin çoğunun birinci sayfalarında konuya önemli derecede yer verdikleri, Mursi’nin ölümünü sahiplenip yas tuttukları görülmüştür. İktidar yanlısı ya da sağ çizgide yer alan gazeteler Mursi'yi "şehit" kabul ederken bu durumu haber metinlerinde ve başlıklarında sıklıkla işlemiştir. Ayrıca Cumhurbaşkanı Erdoğan'ın Mursi için "Şehidimiz" dediğini sık sık dile getirilmiştir.

Mursi'nin tutsaklığını haklı görmeyen bu gazeteler Mursi'nin demokratik seçimlerle cumhurbaşkanlı̆̆ını kazandığı vurgusunu her defasında yeniden üretmiştir. Gazeteler genel anlamda Mursi için "Mısır'ın meşru yollarla seçilmiş ilk ve tek cumhurbaşkanı", "Mısır'ın seçilmiş lideri Mursi" gibi nitelemeler kullanmış̧ır. Mursi' yi şehit kabul eden söz konusu gazeteler Mısır Cumhurbaşkanı Sisi'yi ise, "zalim", "firavun", "Mısır'ın seri katili" olarak nitelendirmiş ve onu Mursi'nin ölümünden sorumlu tutmuşlardır. Bunun yanı sıra kimi gazeteler tarafindan Sisi, köpeğe benzetilerek onunla ilgili daha ağır ifadeler de kullanılmıştır.

İktidar yanlısı ve sağ çizgide yer alan gazeteler, Mursi'nin zulme ve haksızlığa uğradığını her defasında dile getirmişlerdir. Gazeteler bu durumu Mursi'nin parmaklıklar ardındaki fotoğrafına sürekli yer vermesinin yanı sıra haber metinlerinde Mursi'nin hakarete ve işkencelere maruz kaldığını, mahkeme salonunda bile söz hakkı istediği halde kendisine söz hakkı verilmediğini belirterek yansıtmıştır. Gazeteler ayrıca Mursi'nin 6 yıl boyunca sistematik işkenceyle katledildiğini vurgulamış ve ölümünü şüpheli bulmuştur. Bayılmasından sonra uzun süre Mursi'ye müdahale edilmemiş olmasını da eleştiren kimi gazetelerin ayrıca bütün bunlara rağmen Mursi'nin ölümüne kahramanlık ve destansallık katmaya çalıştıkları görülmüştür. Gazeteler, Mursi'nin Sisi'nin darbesiyle görevinden uzaklaş̧ırıldığını, onurlu ve dik bir duruşa sahip olduğunu dile getirmiştir. Ayrıca görmüş olduğu zulme rağmen Mursi'nin cesur ve kararlı bir duruşunun olduğunu sergilemeye gayret göstermiştir.

Sonuç olarak Muhammed Mursi'nin ölümünün üzerine yapılan değerlendirmede, ulusal basınında gazetelerin yayın çizgilerinin haber içeriklerine önemli derecede yansıdığı görülmüştür. Mursi'nin Müslüman bir kimliğe sahip ve davası uğruna tutsak edilmiş olması iddiası sağ çizgide yer alan gazetelerin Mursi'nin ölümünü ya da ölüm şeklini kınamalarına, eleştirmelerine neden olmuştur. Sol çizgide yer alan gazeteler ise Mursi'nin ölümünü normal bir ölüm olarak haberlerinde yansitırken iktidar partisi olan AK Parti'nin ve Cumhurbaşkanı Erdoğan'ın Mursi'nin ölümüne olan tepkisini abartılı bulmuş, onları bu tavır üzerinden eleştirmiştir. Bu durum göstermektedir ki olaylar kilometrelerce uzakta gerçekleşmiş olsa dahi gazeteler kendi yayın çizgilerine göre hareket etmektedir.

\section{Extended Abstract}

The Arab Spring, which started in 2010 and damaged the geography of the Middle East, impacted both governments and populations on the land concerned. Most states' representatives have had to leave the seats of power willingly or forcefully. Both members, for whatever cause, were the focus of international news as well as national news. The news has criticized some of these leaders and embraced some of them. Turkey and the Turkish public supported the activities of Mohammed Morsi, the first elected and ousted fifth president of Egypt. The mindset and religious identity of Morsi, in particular, have played an important role in getting Turkey's help. With the reflection of the Arab Spring on the Egyptian lands, Hüsnü Mubarak's power came to an end and after the elections that 
took place for the first time in a democratic way in Egypt, Mohammed Morsi became the president. Mohammed Morsi, Egypt's overthrown leader, died suspiciously in Cairo on June 17, 2019. Morsi, who has been in jail since the failure of the July 2013 military coup, was suspected of being assassinated after losing his life in the courtroom. The death of Morsi has had significant repercussions in Turkey, even in absentia funeral prayers for Mohammed Morsi around the country has been made. The purpose of the study is to analyse the reflections of the death of Egypt's overthrown leader Mohammed Morsi in the Turkish national press and the scope of its presentation.

Critical discourse analysis method was used in the study. Every discourse structured by sovereignty is historically produced and interpreted. These sovereignty structures are legitimized in the ideologies of powerful groups (Wodak, 2002, p. 12). The purpose of critical discourse analysis, which sees language as a social practice (Wodak \& Meyer, 2009, p. 5) is to critically examine social inequality (Weiss \& Wodak, 2003, p. 15). In the study, the issues of Akşam, Anayurt, Aydınlık, Birgün, Cumhuriyet, Diriliş Postası, Evrensel, Güneş, Karar, Korkusuz, Milat, Milli Gazete, Ortadoğu, Sözcü, Star, Türkgün, Türkiye, Yeni Akit, Yeni Asya, Yeni Birlik, Yeni Çağ, Yeni Mesaj, Yeni Söz, Yeni Şafak and Yurt newspapers between 18-22 June 2019 were examined. Since the issues of newspapers such as Milliyet, Hürriyet and Sabah could not be reached, these newspapers could not be analysed. Discourse analysis was used in the study in which the 5 days process was analysed after the death of Morsi on the first pages of 25 national newspapers.

From the 25 national newspapers analysed in the study on the presentation of the death of the former leader of Egypt, Mohammed Morsi, who died in the courtroom on June 17, it was observed that Aydınlık, Korkusuz, Yeni Mesaj and Yurt newspapers did not include any news on the first pages during the analysis. Although it is seen that the subject is handled in newspapers other than these newspapers, which do not find the subject valuable enough to be included in their news, it has been found that there is a difference in the way they approach the subject depending on the editorial lines of the newspapers.

In general, the newspapers on the left line did not show much interest in the subject. They covered the subject to a small extent on the first pages and showed Morsi's death as a normal death. For Mohammed Morsi, who died after fainting in the courtroom, they used such qualifications as "the overthrowed president of Egypt", "a member of the Muslim Brotherhood Organization", "the former Egyptian President", "the overthrown leader of Egypt." These newspapers, unlike the pro-ruling party newspapers, never mentioned that Morsi was the first democratically elected president. The newspapers put President Erdoğan's statement that Morsi was a martyr on their agenda and criticized the situation indirectly. In addition, they tried to reflect indirectly that "Morsi was not a martyr" by criticizing the pro-government newspapers in such an approach. The party that the leftwing newspapers criticized over Morsi's death was the attitude of the AK Party.

When the right-wing or pro-ruling party newspapers were evaluated, it was seen that most of these newspapers included the subject on the first pages, and they embraced Morsi's death and mourned. While the pro-ruling or right-wing newspapers regard Morsi as a "martyr", they frequently mentioned this in news articles and headlines. In addition, it was frequently mentioned that President Erdoğan said "Our Martyr" for Morsi.

These newspapers, which do not justify Morsi's captivity, have reproduced the emphasis that Morsi won the presidency through democratic elections. Newspapers used qualifications for Morsi in general terms such as "Egypt's first and only elected legitimate president" and "Egypt's elected leader Morsi." The newspapers in question, which accepted Morsi as a martyr, described the Egyptian President Sisi as "cruel", "pharaoh", 
"serial killer of Egypt" and held him responsible for Morsi's death. In addition, some newspapers have referred to Sisi as a dog and used rough expressions about him.

The pro-ruling and right-wing newspapers have always stated that Morsi was subjected to persecution and injustice. Newspapers reflected this situation by stating that Morsi was constantly exposed to his photograph behind bars, and that Morsi was subjected to insult and torture in the news texts and that he was not given the right to speak even though he asked for a voice in the courtroom. Newspapers also emphasized that Morsi was murdered with systematic torture for 6 years and found his death suspicious. Some newspapers, which criticized that Morsi had not been intervened for a long time after fainting, were also found to try to add epicness to Morsi's death. The newspapers stated that Morsi was removed from his task with the coup of Sisi and that he had an honorable and upright stance. In addition, the newspapers tried to show that Morsi had a bold and determined stance despite the persecution.

As a result, in the evaluation of the death of Mohammed Morsi showed that the editorial lines of newspapers in the Turkish national press reflected significantly on their news content. The claim that Morsi was held prisoner for the sake of his cause caused the newspapers on the right line to condemn and criticize Morsi's death or the way he died. The left-wing newspapers, on the other hand, described Morsi's death as a normal death, and found the reaction of the ruling AK Party and President Erdoğan to Morsi's death exaggerated and criticized them over this attitude. This presents that even if the incidents took place miles away, the newspapers act according to their own editorial lines.

\section{Kaynakça}

Akgün, M. ve Senyücel Gündoğar, S. (2014). Mısır Türkiye ilişkilerinde daha iyi bir gelecĕ̌ doğru. İstanbul: TESEV.

Aşkar Karakır, İ. ve Aknur, M. (2015). Devrimler sonrası Arap kadınının siyasi temsili: Bir Arap Bahar1 yanılgısı mı?. Ankara Üniversitesi SBF Dergisi, 70(1), 131-162.

Ayhan, V. (2011). Arap Baharı'nın ABD-Türkiye ilişkilerine etkisi. Ortadoğu Analiz, $3(36), 17-22$.

Bacık, G. (2011). Arap Baharı'ndan Ortadoğu ve Kuzey Afrika'nın geleceğine bakmak. MÜSİAD Çerçeve Dergisi, 57, 16-22.

BBC (2020). Muhammed Mursi kimdir?: Mısır'ın halkoyuyla seçilip darbeyle devrilen eski cumhurbaşkanı, BBC.com/turkce/haberler-dunya-48664537, Erişim Tarihi: 05.01.2020.

Dede, A. (2011). The Arab Uprisings: Debating the Turkish model. Insight Turkey, 13(2), 23-24.

Dışişleri Bakanlığı (2020). Türkiye - Mısır siyasi ilişkileri, MFA.gov.tr/turkiyemisir_siyasi-iliskileri-.tr.mfa, Erişim Tarihi: 14.01.2020.

Doster, B. (2014). Arap Baharı Avrasya-Atlantik rekabetini yorumlamak, BILGESAM: http://www.bilgesam.org/Images/Dokumanlar/0-327-2014090439arapbahariuzerinden -avrasya-atlantik.pdf, Erişim Tarihi: 12.01.2020.

Duran, B. ve Yılmaz, N. (2012). Ortadoğu'da modellerin rekabeti: Arap Baharı'ndan sonra yeni güç dengeleri. Ankara: Seta Yayıncılık.

Göçer, İ. ve Çınar, S. (2015). Arap Baharı'nın nedenleri, uluslararası ilişkiler boyutu ve Türkiye'nin diş ticaret ve turizm gelirlerine etkileri. KAÜ IIBBF Dergisi, 6(10), 51-68. 
Güzelipek, Y. A. (2016). 5. yılında Arap Baharı: Arap uyanışı mı yoksa bölgesel bir kaos mu?. Yeni Ortadoğu: Toplum, Siyaset ve Ekonomi Konferansl, 5-10.

Kaya, E. E. (2018). 2000'li yıllardan günümüze Türkiye-Mısır siyasi ve ekonomik ilişkilerinin seyri, M. Ercan (der.). 21. yüzyılda küresel ve bölgesel aktörler bağlamında Türk dış politikası. İstanbul: Efe Akademi Yayınları.

Kışlakçı, T. (2012). Arap Baharı. İstanbul: İlimyurdu Yayıncılık.

Koraltan, F. H. (2016). Bir devrim süreci: Arap Baharı. Yeni Ortadoğu: Toplum, Siyaset ve Ekonomi Konferansi, 30-36.

Özer, Ö. (2018). Gökyüzüne çı̆̆lık (Öncülerden eleştirel söylem yaklaşımları ve özgün çözümlemeler). Konya: Literatürk Yayınları.

Öztoprak, P. (2012). Ortadoğu'nun demokratikleşme süreci ve Türkiye. Akademik Analiz, 1(4), 9-14.

Sarıaslan, F. (2019). Türkiye-Mısır ilişkilerinde ekonomik dinamiklerin etkisi. Erciyes Üniversitesi İktisadi ve İdari Bilimler Fakültesi Dergisi, 54, 526-559.

Siyaset (2020). Türkiye-Mısır ilişkileri, Siyasetdergisi.com.tr/turkiye-misir-iliskileri/, Erişim Tarihi: 14.01.2020.

Taş, R. (2012). Ortadoğu'daki gelişmelerin ekonomik anlamı ve küresel, bölgesel ve Türkiye ekonomisi üzerindeki potansiyel etkileri. Ortadoğu Raporu. Ankara: Turgut Özal Üniversitesi Yayınları.

Telci, İ. N. (2014). Mısır devrimi sürecinde işçi hareketinin rolü. Türkiye Ortadoğu Çalışmalar Dergisi, 1(1), 81-112.

Telci, İ. N. (2017). Arap isyanları sürecinde Türkiye-Mısır ilişkilerinin dönüşümü. K. İnat, A. Aslan ve B. Duran (Der.). Kuruluşundan bugüne AK Parti dış politika, Ankara: SETA.

Telli, A. (2012). Misır Devrimi’nde sosyal medyanın rolü. Bilge Strateji, 4(7), 65-91.

Usul, A. R. (2011). Arap halk hareketleri, bölgede demokratikleşme imkânları, Libya ve Türkiye'nin tutumu. http://www.gpotcenter.org/dosyalar/resul_presentation_1lapr 2011.pdf., Erişim Tarihi: 10.01.2020.

Uysal, A. (2014). Mısır değişimin buruk tadı ya da çıkmaz sokak?. Stratejik Düşünce Dergisi, (54), 58-61.

van Dijk, A. T. (2009). Criticial discourse studies: A sociocognitive approach. R. Wodak and M. Meyer (Eds.), Methods of criticial discourse analysis. (p. 62-85). London: Sage.

Weiss, G. and Wodak, R. (2003). Theory, interdisciplinarity and critical discourse analysis. G. Weiss and R. Wodak (Eds.), Critical discourse analysis: Theory and interdisciplinarity. (p. 1-32). Palgrave: MacMillan.

Wodak, R. (2002). Aspects of critical discourse analysis. Zeitschrift für Angewandte Linguistik, 36(10), 5-31.

Wodak, R. and Meyer, M. (2009). Criticial discourse analysis: History, agenda, theory and methodology. R. Wodak and M. Meyer (Eds.), Methods of criticial discourse analysis. (p. 1-33). London: Sage. 


\section{Gazeteler}

Akşam, Anayurt, Aydınlık, Birgün, Cumhuriyet, Diriliş Postası, Evrensel, Güneş, Karar, Korkusuz, Milat, Milli Gazete, Ortadoğu, Sözcü, Star, Türkgün, Türkiye, Yeni Akit, Yeni Asya, Yeni Birlik, Yeni Çăg, Yeni Mesaj, Yeni Söz, Yeni Şafak ve Yurt gazetelerinin 18-22 Haziran 2019 tarihleri arasındaki sayıları incelenmiştir.

Araştırmacı Katkı Oranı: Araştırmacılar çalışmaya eşit oranda katkı sunmuştur.

Destekleyen Kurum/Kuruluşlar: Herhangi bir kurum/kuruluştan destek alınmamıştır.

Çıkar Çatışması: Herhangi bir çıkar çatışması bulunmamaktadır. 